\title{
Sexual Dimorphism and Gender in Infectious Diseases
}

\author{
Laetitia Gay ${ }^{1 \dagger}$, Cléa Melenotte ${ }^{1,2 \dagger}$, Ines Lakbar ${ }^{3 \dagger}$, Soraya Mezouar ${ }^{1}$, Christian Devaux ${ }^{1}$, \\ Didier Raoult ${ }^{1}$, Marc-Karim Bendiane ${ }^{2}$, Marc Leone ${ }^{1,3 \neq^{\star}}$ and Jean-Louis Mège ${ }^{1 \neq}$ \\ ${ }_{1}^{1}$ Aix-Marseille Univ, IRD, APHM, MEPHI, IHU-Méditerranée Infection, Marseille, France, 2 Aix-Marseille Univ, INSERM, IRD, \\ SESSTIM, Economy and Social Science, Health Care Systems and Societies, Marseille, France, ${ }^{3}$ Department of Anaesthesia \\ and Intensive Care, Hôpital Nord, Aix-Marseille Univ, APHM, Marseille, France
}

Epidemiological studies and clinical observations show evidence of sexual dimorphism in infectious diseases. Women are at less risk than men when it comes to developing most infectious diseases. However, understanding these observations requires a gender approach that takes into account an analysis of both biological and social factors. The host's response to infection differs in males and females because sex differences have an impact on hormonal and chromosomal control of immunity. Estradiol appears to confer protective immunity, while progesterone and testosterone suppress anti-infectious responses. In addition, genetic factors, including those associated with sex chromosomes, also affect susceptibility to infections. Finally, differences in occupational activities, lifestyle, and comorbidities play major roles in exposure to pathogens and management of diseases. Hence, considering sexual dimorphism as a critical variable for infectious diseases should be one of the steps taken toward developing personalized therapeutic approaches.

Keywords: sexual dimorphism, gender, infectious disease, sex hormones, personalized medicine

\section{INTRODUCTION}

In infectious diseases, the health differences between men and women are a result of interactions between biological and sociocultural factors. Hence, age, comorbidities, genetic predispositions, geographical distribution of pathogens, health behaviors, and hormonal influences are just some of the examples of the diversity of mechanisms explaining sex differences (1). These different factors make it difficult to discriminate what is related to sex as a biological entity and gender as a social construct. Indeed, comorbidities, exposure to pathogens, health behaviors, and access to healthcare interfere with the development of most infectious diseases (Figure 1) (2). Sexual dimorphism also affects the processes, including the immune system, used by the host to fight against infection $(3,4)$.

In infectious diseases, animal models and epidemiological studies provide strong support for sexual dimorphism, whereas mechanistic studies in patients are less conclusive. One reason for this dissociation is that biological studies are too reductionist, do not integrate sociocultural factors, and involve patients of each sex who have already developed the disease.

The recent events of the COVID-19 pandemic show the importance of sex differences in susceptibility to viral infections. This review is dedicated to updating the role of sexual dimorphism and gender differences in infectious diseases, here with the goal of providing a mechanistic approach toward infectious diseases. 


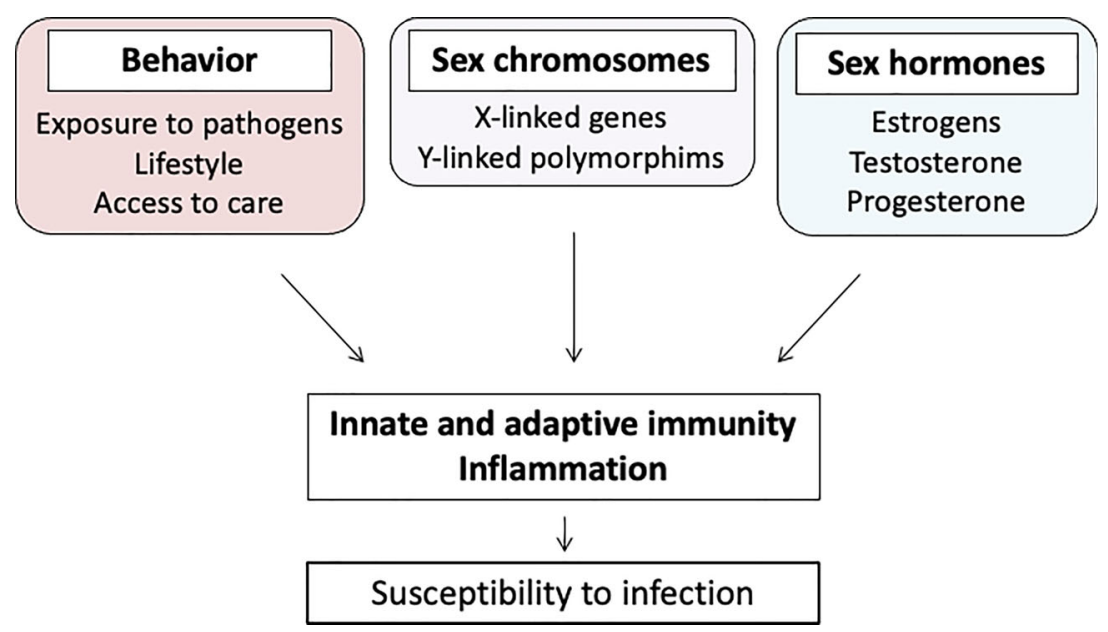

FIGURE 1 | Multifactorial mechanisms of gender dimorphism.

\section{Search Strategy and Selection Criteria}

For the purpose of the current review, we conducted a nonsystematic search in Medline (through PubMed) and Google Scholar databases using the following keywords: "sex", "gender", "infection", "bacteria", "viruses", "parasites", "men”, "women”, "ratio", and "difference". The search was conducted with no restrictions on language or type of study, from inception to August 2020. A total of 150 references were included in the final qualitative analysis.

\section{SEXUAL DIMORPHISM AND ANTI- INFECTIOUS IMMUNITY}

Most epidemiological studies have shown that being a man is a risk factor for infectious diseases. Hence, women exhibit a higher ability to recognize pathogens, recruit more innate immune cells, and mount stronger adaptive immune responses than men. As a large body of literature has addressed the role of sexual dimorphism in anti-infectious immunity (5), our aim was to provide a summary of critical immune issues.

The innate recognition of pathogens involves numerous membrane and cytosolic molecules, including Toll-like receptors (TLRs). Whereas TLR4 expression is higher in neutrophils and macrophages from males, that of TLR7 is higher in females; this may be related to the hypothesis that $\mathrm{X}$ chromosome-encoded TLR7 can escape $\mathrm{X}$ inactivation, resulting in higher levels of TLR7 expression in females $(5,6)$. Notably, Xinactivation escape is also responsible for the female bias in autoimmune diseases (7). Furthermore, sexual dimorphism may affect the regulatory pathway of TLR7. Hence, the CD200 receptor, which is the receptor of the OX-2 glycoprotein, controls TLR7 responses. In its absence, type I interferon (IFN) production and viral clearance are increased in female mice infected with hepatitis coronavirus (8). Also, the lower expression of TLR9 in female mice infected with cytomegalovirus (CMV) likely accounts for the higher susceptibility and lower activation of their immune system (9).

The recruitment of innate immune cells is driven by inflammatory mediators. In response to lipopolysaccharide (LPS), circulating mononuclear cells from men produce more tumor necrosis factor (TNF) than those from women (10). This finding is consistent with the observation of sepsis, in which men produce higher inflammatory cytokines and lower antiinflammatory cytokines than women $(11,12)$. On the other hand, mononuclear cells from men produce more IL-10, an immunoregulatory cytokine of innate and adaptive immune responses, in response to viral infections via TLR8 and TLR9 pathways, than mononuclear cells of women (13). It should be noted that the reaction to LPS can be influenced by the hypothalamic-pituitary-adrenal axis, in particular by the cortisol response to acute stress. Female mice were found to have a significantly higher concentration of cortisol when treated with LPS (14). In contrast, human immunodeficiency virus (HIV)-infected women showed blunted cortisol response to acute stress (15).

Moreover, adaptive immune responses seem more efficient in women than in men. The antibody response of women is usually higher than that of men (16). Women exhibit an increased number of immunoglobulin-producing $B$ cells and higher baseline immunoglobulin levels. The repertoire of B cells has been reported to amplify this difference (17). This is illustrated by differences in antibody repertoire and avidity in men and women following H1N1 vaccination (18). Sexual differences have also been reported when it comes to cellular immune response. Women have higher baseline $\mathrm{CD} 4^{+} \mathrm{T}$ cell counts and higher $\mathrm{CD}^{+} / \mathrm{CD}^{+}$ratios than age-matched men, whereas men have a higher baseline $\mathrm{CD}^{+} \mathrm{T}$ cell number (16). After in vitro stimulation of mononuclear cells, women have been shown to have higher numbers of activated and proliferating $\mathrm{T}$ cells (16). It has been established that human leukocytes antigen (HLA) 
molecules shape the repertoire of T cell receptors (TCRs), as shown by HLA-mediated use of TCR V beta chains. Their use differs in men and women and is likely under steroid control (19). Hence, the fight of the immune system against infectious pathogens relies on sexual dimorphism.

\section{SEX HORMONES AND CONTROL OF INFECTIONS}

\section{Sex Hormones in Males and Nonpregnant Females}

Sex hormones modulate immune responses through specific receptors, which are expressed by most immune cells, including lymphocytes, macrophages, and dendritic cells (DCs) (20). After the hormone binds to its receptor, the hormonereceptor complex moves to the nucleus of the immune cell and binds to promoters that contain specific hormonal response elements (21). These hormonal response elements are present in the promoters of several innate immunity genes, suggesting that sex hormones may directly affect the functions of immune cells (Figure 2). Estradiol has probably been the most extensively investigated sex hormone. Low estradiol concentrations favor Th1-type responses and cell-mediated immunity, whereas high estradiol concentrations induce Th2-type responses and humoral immunity $(22,23)$. Progesterone and testosterone are known to have broad anti-inflammatory effects and to suppress innate immune responses $(22,24)$.

Sex hormones play an important role in susceptibility to infections, and tuberculosis is one of the most convincing examples, even though the evidence of such is based on unethical experiments. In 1969, research showed that the mortality rate of Mycobacterium tuberculosis infection was markedly lower in castrated men than intact men (25). In contrast, the tuberculosis-associated mortality rate in ovariectomized women is higher than in non-ovariectomized women $(7.0 \%$ vs. $0.7 \%)$ (26). These two studies have shed light on the protective role of castration and the deleterious role of oophorectomy in humans, suggesting that testosterone may favor mycobacterial diseases, whereas estrogen may be protective. In a similar vein, postmenopausal women with low estrogen levels are more susceptible to opportunistic infections, as shown by an increased risk of pulmonary nontuberculous mycobacterial infections (27). It is noteworthy that, in a small group of HIV-infected women treated with hormone replacement therapy, a reduced risk of death was observed (28).

Clinical observations are not sufficient to understand the effects of sex hormones in susceptibility to infection, and only

\begin{tabular}{|c|c|c|c|}
\hline & Estrogens & Androgens & Progesterone \\
\hline T cells & $\begin{array}{l}\uparrow \text { Th1 differentiation } \\
\uparrow \mathrm{TNF} \text { IL-1 } \beta \text {, IFN- } \gamma, \mathrm{IL}-4 \\
\uparrow \text { Treg and activation } \\
\uparrow \text { T-cell apoptosis }\end{array}$ & $\begin{array}{l}\downarrow \text { Th1 responses } \\
\downarrow \text { T-cell proliferation } \\
\downarrow \text { IL-4 production } \\
\downarrow \text { Treg cells }\end{array}$ & $\downarrow$ Response \\
\hline & $\begin{array}{l}\uparrow \text { Activity } \\
\uparrow \text { Antibody production }\end{array}$ & $\downarrow$ Antibody production & $\downarrow \mathrm{CD} 80$ and CD86 \\
\hline$\underset{\text { Macrophages }}{(}$ & $\begin{array}{l}\uparrow \text { Phagocytosis } \\
\uparrow \downarrow \text { TNF, IFN- } \vee \text { IL-6, IL-10 } \\
\uparrow \text { TLR-4 expression } \\
\downarrow \text { Nitrite }\end{array}$ & $\begin{array}{l}\downarrow \text { Phagocytosis } \\
\downarrow \text { TNF, iNOS and NO } \\
\downarrow \text { TLR-4 expression } \\
\uparrow \text { IL-10, TGF } \beta\end{array}$ & $\begin{array}{l}\downarrow \text { iNOS and NO } \\
\downarrow T N F, I L-1 \beta\end{array}$ \\
\hline NK cells & $\begin{array}{l}\uparrow \text { IFNy } \\
\uparrow \text { Granzyme B } \\
\downarrow \text { FASL }\end{array}$ & ND & $\begin{array}{l}\uparrow \text { Apoptosis } \\
\text { (caspase dependent) }\end{array}$ \\
\hline thes & $\begin{array}{l}\uparrow \text { Maturation } \\
\uparrow \text { Activation } \\
\uparrow \text { TLR-7and TLR-9 } \\
\uparrow \text { CCL2, IL-6, IL-10, CXCL8 }\end{array}$ & $\downarrow I L-1 \beta$, IL- 6 and TNF & $\begin{array}{l}\downarrow \mathrm{CD} 40, \mathrm{CD} 80, \mathrm{CD} 86 \\
\uparrow \mathrm{IL}-18 \text { and IL-10 } \\
\downarrow T N F, \text { IL- } 1 \beta\end{array}$ \\
\hline Neutrophils & $\begin{array}{l}\uparrow \text { Numbers } \\
\uparrow \text { Degranulation } \\
\uparrow \text { Elastase release }\end{array}$ & $\begin{array}{l}\uparrow \text { Numbers } \\
\downarrow \text { Kinases } \\
\downarrow \text { Leukotriene formation }\end{array}$ & ND \\
\hline $\begin{array}{l}\text { Do } \\
\text { Eosinophils }\end{array}$ & $\begin{array}{l}\downarrow \text { Numbers } \\
\downarrow \text { Mobilization } \\
\uparrow \text { Degranulation }\end{array}$ & $\downarrow$ Degranulation & $\begin{array}{l}\uparrow \text { Numbers } \\
\uparrow \text { Degranulation }\end{array}$ \\
\hline
\end{tabular}

FIGURE 2 | Effects of sex hormones on the immune system. Estrogens, progesterone, and androgens may directly affect immune cell functions. Generally, testosterone and progesterone are anti-inflammatory, suppressing several of the immune responses necessary for inflammation, whereas estradiol has bipotential effects: proinflammatory at low concentrations and anti-inflammatory at high concentrations. CCL, CC-chemokine ligand; CXCL, CXC-chemokine ligand; FASL, FAS ligand; iNOS, inducible nitric oxide synthase; ND, not defined; NO, nitric oxide; Treg, regulatory T. 
TABLE 1 | Effect of sex hormones on diseases in animal models.

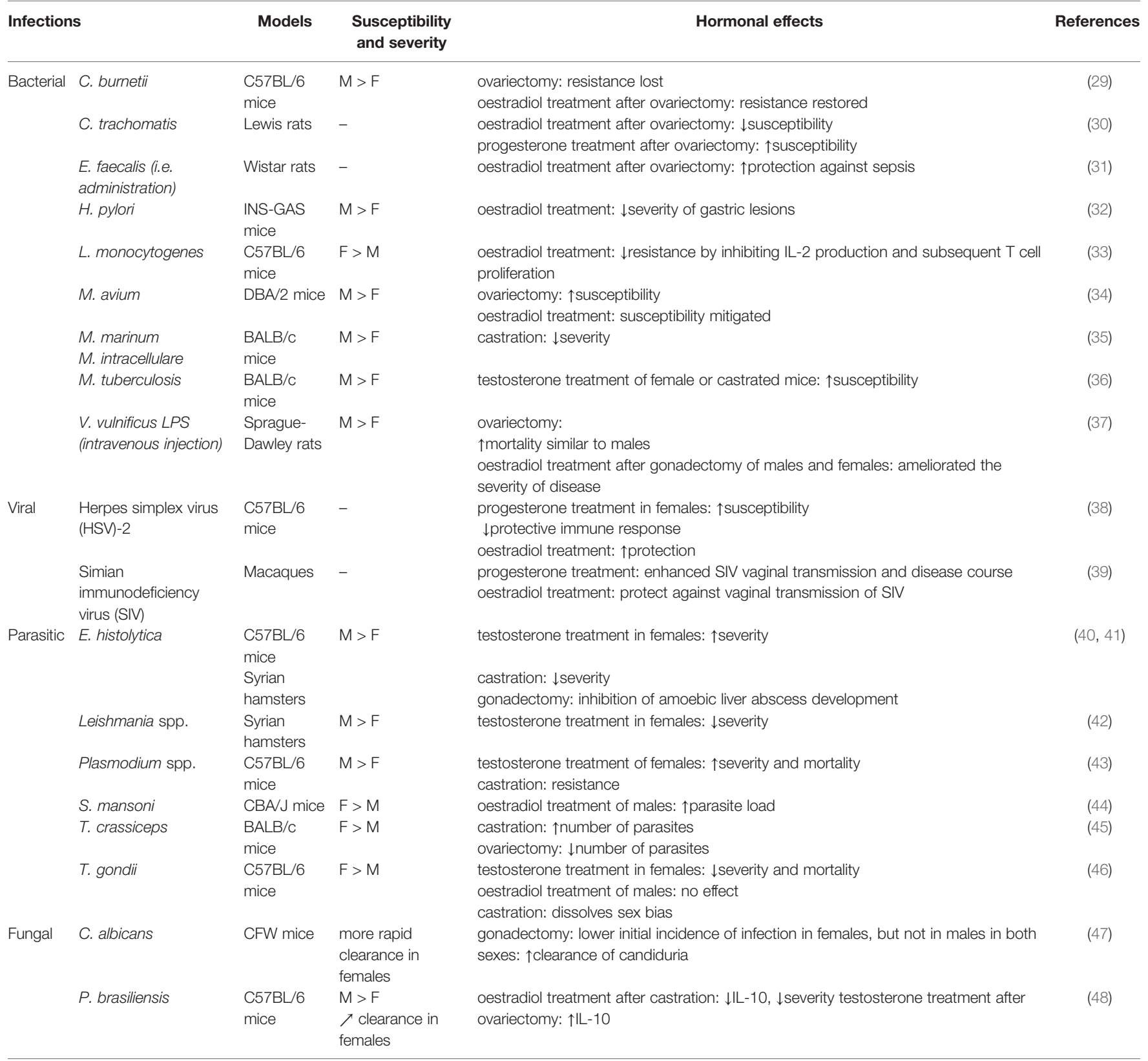

Susceptibility to infection and the effects of sex hormones are described by comparing males $(M)$ and females $(F)$. The term ovariectomy is used only in the case of females, the term castration only for males and the term gonadectomy when it is used on males and females.

experimental models clearly depict the susceptibility and severity of infection as well as its pathophysiological mechanisms (Table 1). The castration of male mice reduces host sensitivity to certain infections, whereas the administration of testosterone into female mice increases their susceptibility to these infections $(35,40-43,49)$. Estradiol protects female rats against bacterial sepsis and attenuates tissue lesions induced by Helicobacter pylori in mice $(31,32,37)$. In Coxiella burnetii infection of mice, tissue infection and granulomatous responses are largely under the control of estrogens: the treatment of ovariectomized mice with $17 \beta$-estradiol reduces bacterial loads and granuloma numbers (29). We have clearly shown that the response to $C$. burnetii infection is sex dependent and that sex hormones are responsible for more than $60 \%$ of gene modulation in this specific infection (50). These modulated genes in infected females are involved in the circadian rhythm pathway, such as Clock (down-modulated) and Per (up-regulated), which interfere with the production of estradiol (51). In infected males, modulated genes are associated with an anti-inflammatory response, in particular, IL-10 overproduction, which is known to be associated with a progression toward persistent $C$. burnetii infection $(52,53)$. 
Some pathogens have evolved mechanisms that can manipulate host sex hormone production (21). Schistosoma haematobium produces an estrogenic compound that antagonizes both the signaling and expression of estrogen receptors, favoring its replication (54). Similarly, Taenia crassiceps enzymatically reduces testosterone concentrations and increases estradiol concentrations, and these effects promote the reproduction of parasites in male rodents (55). Androgen response elements have been identified in hepatitis B virus (HBV), allowing testosterone to affect $\mathrm{HBV}$ replication by direct binding to these elements (56). Interestingly, the genome of human papillomavirus (HPV) high-risk types 16 and 18 contains a progesterone response pattern that can stimulate HPV replication, playing an important role in the HPVinduced transformation process (57). Thus, increased progesterone concentrations may explain the higher frequency of malignant HPV lesions in women than in men. Progesterone inhibits the transition of Candida albicans into a hyphal form, whereas estradiol stimulates this transition, increasing fungal virulence (58). In fact, an important corpus of data clearly indicates that sex hormones play a major role in host defense and microorganism lifecycles.

\section{Sex Hormones in Pregnant Women}

Pregnancy is a period of major hormonal change with a peculiar susceptibility to infections and a risk of complications for the fetus and mother. During the first trimester, the risk of transmitting infections to the fetus is rare but often results in miscarriage, while infections in the third trimester can result in maternofetal complications (Table 2) (3, 71). Susceptibility to listeriosis, toxoplasmosis, candidiasis, and $\mathrm{HIV}$ infection is known to increase during pregnancy (72). The risk of contracting listeriosis is 20 times higher in pregnant women than in nonpregnant women, and the risk of toxoplasmosis seroconversion increases by 2.2 times during pregnancy (3).

Infection severity is increased in pregnant women; they are seven times more likely to be hospitalized, twice more likely to die from an influenza virus, and three times more likely to develop severe dengue and lethal Plasmodium falciparum infections than nonpregnant women (3, 73-75). Pregnancy complications have been identified in more than $50 \%$ of pregnant women infected with $C$. burnetii infection (4). They include spontaneous abortion (26\%), premature delivery (45\%), or intrauterine growth restriction (5.3\%) (4, 60, 61). Although women likely seem to be protected from infectious risk via estrogens, clinical observations suggest that, during pregnancy, high concentrations of estrogens are detrimental for the host response to infection (Figure 3).

During the third trimester, high concentrations of estradiol and progesterone prevent efficient Th1 immune responses and promote immunoregulatory Th2 immune responses, which is essential for the success of the fetal graft $(76,77)$. Unfortunately, the expansion of Th2 cells, which are known to decrease the robustness of protective cell-mediated immunity, is also, at least partially, responsible for altered immune responses to infections, which may account for the prevalence and severity of infections during pregnancy $(78,79)$.

\section{GENETIC FACTORS AND SEXUAL DIMORPHISM}

Although the Y-chromosome, which is found only in men, encodes about 100 genes, 1,100 genes are expressed on the $\mathrm{X}$-chromosome, which is shared by both men and women, including a large number of genes related to innate and adaptive immune systems. Among them there are genes encoding pattern recognition receptors (such as TLR7 and TLR8) (80) or transcriptional effectors (NF-אB) (81). To prevent excessive $\mathrm{X}$-chromosome responses in women, one of the two X-chromosomes is inactivated. However, $15 \%$ of the $\mathrm{X}$ genes escape inactivation, and their copy number is higher in women than in men, which accounts for the increased risk of autoimmunity in women $(6,82)$. Similarly, the sex chromosomes show an unbalanced microRNA (miRNA) repartition. Indeed, the X-chromosome contains 113 miRNAs (10\% of all miRNAs), whereas only two miRNAs are found in the Y-chromosome (83). These miRNAs, which are involved in the response to infection, are critical regulators of the immune response (84). As an example, mRNA-223 controls susceptibility to $M$. tuberculosis infection by regulating lung neutrophil recruitment (85). The incomplete inactivation of the Xchromosome leads to a higher expression of miRNAs in women. These differences attributable to $\mathrm{X}$-chromosome inactivation contribute to sex differences in immune responses and, therefore, in susceptibility to infections. However, murine models could be considered biased for sex hormone analysis. The four core genotype mouse model enables the study of differences in gene expression solely due to sex chromosome complement without involvement of sex hormones (86). Such an approach is useful to assess the role of IL-1 receptor-associated kinase-1 (IRAK1), CD40 ligand (CD40LG), C-X-C motif chemokine receptor 3, and IL13RA1 or TLR7 genes known to escape the X-related inactivation process in infectious diseases $(6,87-89)$. These findings highlight enhanced female immune response to infectious agents through the involvement of $\mathrm{X}$-chromosome-linked genes.

Chromosome polymorphism affects the severity of infections. Indeed, a single nucleotide polymorphism in the X-chromosome is associated with slow progression to AIDS in women but not in men (90). TLR8 gene polymorphisms on X chromosomes are related to susceptibility to tuberculosis, particularly in boys (91, 92). Other genetic variations independent of sex chromosomes participate in sexual dimorphism, including IL-6 promoter polymorphisms associated with the development of chronic hepatitis $\mathrm{C}$ virus $(\mathrm{HCV})$ infection, which is primarily reported in men (93). In contrast, different polymorphisms in the gene encoding CTLA-4 associated with HCV infection recovery are more frequent in women (94). In the context of COVID-19, it has been shown that the ACE-2 receptor, known to recognize SARS-CoV2, is encoded by the X chromosome, which may partly explain the sexual dimorphism of COVID-19 (95).

Genetic variations in the $\mathrm{Y}$-chromosome increase mouse susceptibility to influenza A virus infection (96) and have a 
TABLE 2 | Infections that cause adverse pregnancy or foetal outcomes.

\begin{tabular}{|c|c|c|c|c|c|c|}
\hline Infection & & Most at-risk & Maternal clinical manifestations and & Maternal risk of & Foetal risk & References \\
\hline Bacterial & B. melitensis & 1st trimester & no specific clinical sign & yes & $\begin{array}{l}\text { spontaneous abortion } \\
\text { preterm birth } \\
\text { congenital brucellosis } \\
\text { mortality }\end{array}$ & (59) \\
\hline & C. burnetii & 2-3rd trimester & higher risk of persistent $C$. burnetii infection & yes & $\begin{array}{l}\text { intrauterine growth restriction } \\
\text { spontaneous abortion } \\
\text { preterm birth } \\
\text { foetal demise }\end{array}$ & $(60,61)$ \\
\hline & $\begin{array}{l}\text { L. } \\
\text { monocytogenes }\end{array}$ & 3rd trimester & sepsis, meningitis, rhombencephalitis & unknown & $\begin{array}{l}\text { spontaneous abortion } \\
\text { preterm birth } \\
\text { serious neonatal disease } \\
\text { foetal demise }\end{array}$ & $(3,62)$ \\
\hline & C. trachomatis & all & no specific clinical sign & unknown & $\begin{array}{l}\text { spontaneous abortion } \\
\text { preterm birth } \\
\text { premature rupture of membranes } \\
\text { low birth weight }\end{array}$ & (63) \\
\hline & $\begin{array}{l}\text { Group B } \\
\text { Streptococcus }\end{array}$ & delivery & bacteraemia, sepsis pyelonephritis, & unknown & $\begin{array}{l}\text { preterm birth } \\
\text { neonatal infection: sepsis, meningitis, } \\
\text { pneumonia }\end{array}$ & $(64)$ \\
\hline Viral & Zika & 1st trimester & no specific clinical sign & unknown & $\begin{array}{l}\text { microcephaly } \\
\text { ocular abnormalities } \\
\text { foetal demise }\end{array}$ & $(65,66)$ \\
\hline & Parvovirus B19 & $\begin{array}{l}\text { 1st and 2nd } \\
\text { trimesters }\end{array}$ & acute arthritis and arthralgias & unknown & $\begin{array}{l}\text { spontaneous abortion } \\
\text { foetal complications (severe anaemia, } \\
\text { hydrops fetalis) }\end{array}$ & $(67)$ \\
\hline & Hepatitis B & 3rd trimester & no specific clinical sign & unknown & $\begin{array}{l}\text { low birth weight } \\
\text { preterm birth } \\
\text { perinatal transmission }\end{array}$ & $(68)$ \\
\hline & Hepatitis E & 3rd trimester & fulminant hepatic failure & yes & $\begin{array}{l}\text { preterm birth } \\
\text { mortality }\end{array}$ & (69) \\
\hline & $\begin{array}{l}\text { Herpes simplex } \\
\text { virus }\end{array}$ & 3rd trimester & no specific clinical sign & unknown & $\begin{array}{l}\text { spontaneous abortion } \\
\text { intrauterine growth restriction } \\
\text { congenital and neonatal herpes } \\
\text { infections }\end{array}$ & (69) \\
\hline & Influenza virus & 3rd trimester & $\begin{array}{l}\text { severe disease, pneumonia, } \\
\text { cardiopulmonary event }\end{array}$ & yes & $\begin{array}{l}\text { spontaneous abortion } \\
\text { preterm birth } \\
\text { mortality }\end{array}$ & (70) \\
\hline & Measles virus & 3rd trimester & $\begin{array}{l}\text { severe disease, respiratory complications, } \\
\text { pneumonia, encephalitis }\end{array}$ & yes & $\begin{array}{l}\text { spontaneous abortion } \\
\text { preterm birth } \\
\text { congenital defects }\end{array}$ & (3) \\
\hline & Varicella virus & 3rd trimester & severe disease, pneumonia & yes & $\begin{array}{l}\text { mortality } \\
\text { congenital varicella syndrome }\end{array}$ & (69) \\
\hline & CMV & all & no specific clinical sign & unknown & $\begin{array}{l}\text { intrauterine growth restriction } \\
\text { congenital infection } \\
\text { mortality }\end{array}$ & (69) \\
\hline & Ebola virus & all & severe bleeding & yes & $\begin{array}{l}\text { spontaneous abortion } \\
\text { preterm birth }\end{array}$ & (69) \\
\hline Parasitic & $\begin{array}{l}\text { Plasmodium } \\
\text { spp. }\end{array}$ & $\begin{array}{l}\text { first half of } \\
\text { pregnancy }\end{array}$ & $\begin{array}{l}\text { severe anaemia, renal failure, higher } \\
\text { frequency of lymphadenopathy }\end{array}$ & yes & $\begin{array}{l}\text { low birth weight } \\
\text { intrauterine growth restriction } \\
\text { preterm birth }\end{array}$ & (3) \\
\hline & T. gondii & 1st trimester & no specific clinical sign & unknown & $\begin{array}{l}\text { congenital diseases (microcephaly, } \\
\text { intracranial calcifications) }\end{array}$ & (3) \\
\hline
\end{tabular}

Infections that can cause adverse pregnancy or foetal outcomes and are described according to the stage of pregnancy.

direct effect on the survival of coxsackievirus B3-infected mice (97). Genes encoding resistance to Plasmodium chabaudi, Leishmania mexicana, or mousepox infection have been identified in mice on autosomal chromosomes (Table 3), and these loci confer greater resistance to females (98-100). Thus, genetic resistance to infection is partly sex dependent, but this association requires further investigation.

\section{SEXUAL DIMORPHISM IN INFECTIOUS DISEASES: CLINICAL EVIDENCE}

Epidemiological studies and clinical observations provide clear evidence of sexual bias in infectious diseases and offer insights into exploring the role of sexual dimorphism in infectious diseases. These studies refer to the differences of susceptibility 


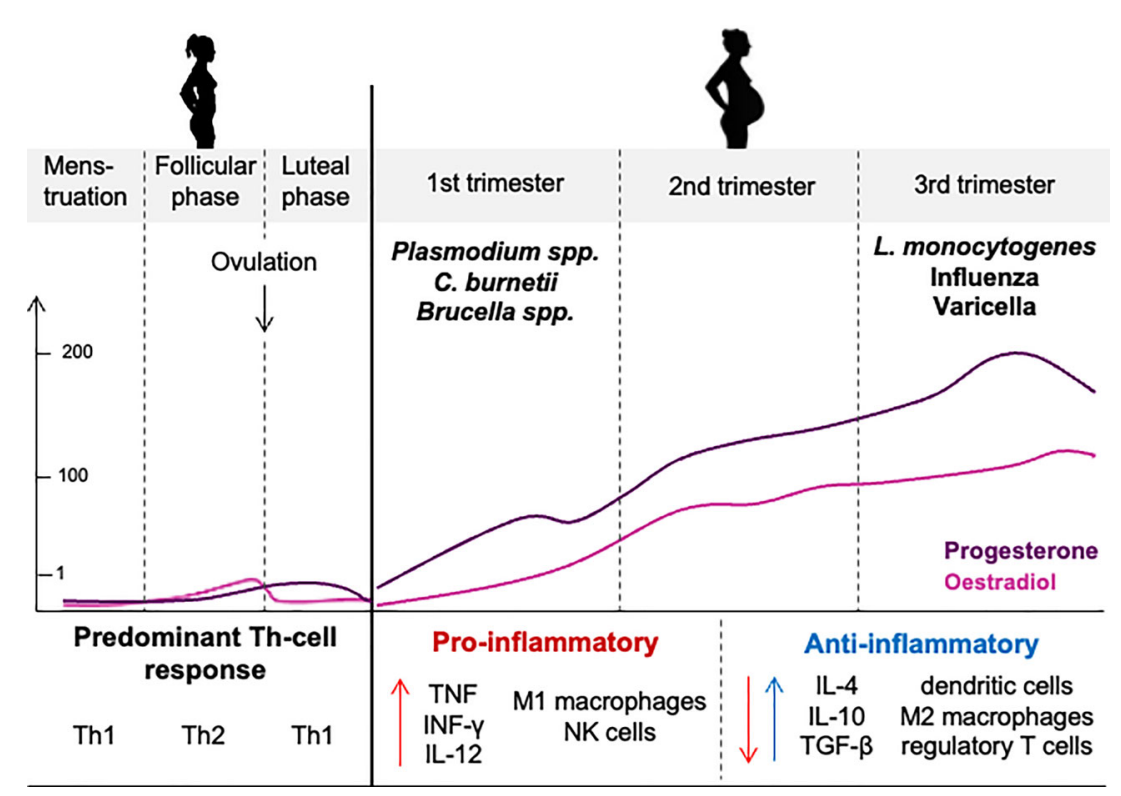

FIGURE 3 | Hormone levels and immune responses during the menstrual cycle and pregnancy. Increased hormonal concentrations during pregnancy contribute to the immune shifts to support a successful pregnancy but also increase the susceptibility of women to infectious disease.

and clinical presentation in men and women according to the site of infection or the nature of the microorganism.

\section{Sexual Dimorphism Related to the Site of Infection}

The incidence of urinary tract infections, genital infections, infective endocarditis, and respiratory tract infections differs between men and women. We have summarized the main findings about sexual dimorphism in infections in which anatomical differences might play a role in Figure 4.

Urinary tract infections are the most frequent infections worldwide, occurring in 53,067 cases per 100,000 women and 13,689 cases per 100,000 men. Women from the ages of 16 to 35 are about 35 times more likely to develop urinary tract infections than men (101). Although anatomical differences have long been proposed as the main explanation for the predominance of women experiencing more urinary tract infections, other factors are emerging that more fully explain the increased risk of urinary tract infections in women; these factors include sexual intercourse, antimicrobial exposure, estrogenic status, contraception influencing the vaginal microbiota, and any intervention resulting in the loss of normally protective Lactobacillus spp $(102,103)$. The distribution of the causative agents of urinary tract infections also differs in men and women: Escherichia coli, Klebsiella pneumonia, and Streptococcus agalactiae are more frequently found in women, whereas Enterococcus faecalis, Proteus mirabilis, and Pseudomonas aeruginosa are more often found in men (104). Cellular factors also differ according to sex. Hence, the epithelial cells of the penile skin appear to be more resistant to HPV infection than the cervical epithelium, the former being keratinized and the latter mucosal (105).

Infective endocarditis exhibits a male/female $(\mathrm{M} / \mathrm{F})$ sex ratio above two (106). The site of infection, which is the injured valve, is more often the mitral valves in women ( $50 \%$ vs. $36 \%, p=0.02)$ and the aortic valves in men (46\% vs. $31 \%, p=0.02)(106)$. Infective endocarditis-associated in-hospital death is higher in women than in men. Nevertheless, it is difficult to establish an

TABLE 3 | Genetic susceptibility to infections in mice.

\begin{tabular}{|c|c|c|c|}
\hline Infections & Genetic variation & Effect of genetic variation & References \\
\hline Influenza A virus & chromosome $Y$ & $\begin{array}{l}\nearrow \text { susceptibility to infection of males } \\
\nearrow \text { pathogenic immune responses in lungs }\end{array}$ & $(96)$ \\
\hline Coxsackievirus B3 & $\begin{array}{l}\text { chromosome } Y \\
\text { Resistance genes }\end{array}$ & $\begin{array}{l}\nearrow \text { mortality in infected males } \\
\text { Effect of resistance genes }\end{array}$ & $(97)$ \\
\hline P. chabaudi & Char 1-4 & greater resistance of females (Char 2, Char 4) & (98) \\
\hline L. mexicana & Scl-2 & greater resistance of females & (99) \\
\hline Mousepox & Rmp1-4 & greater resistance of females (Rmp 2, Rmp 4) & $(100)$ \\
\hline
\end{tabular}

Genetic variations in the $Y$ chromosome influence the survival of male mice following influenza A virus and coxsackievirus B3 infection. Resistance genes have been identified, and the effects of these genes confer greater resistance to infections for female mice. 


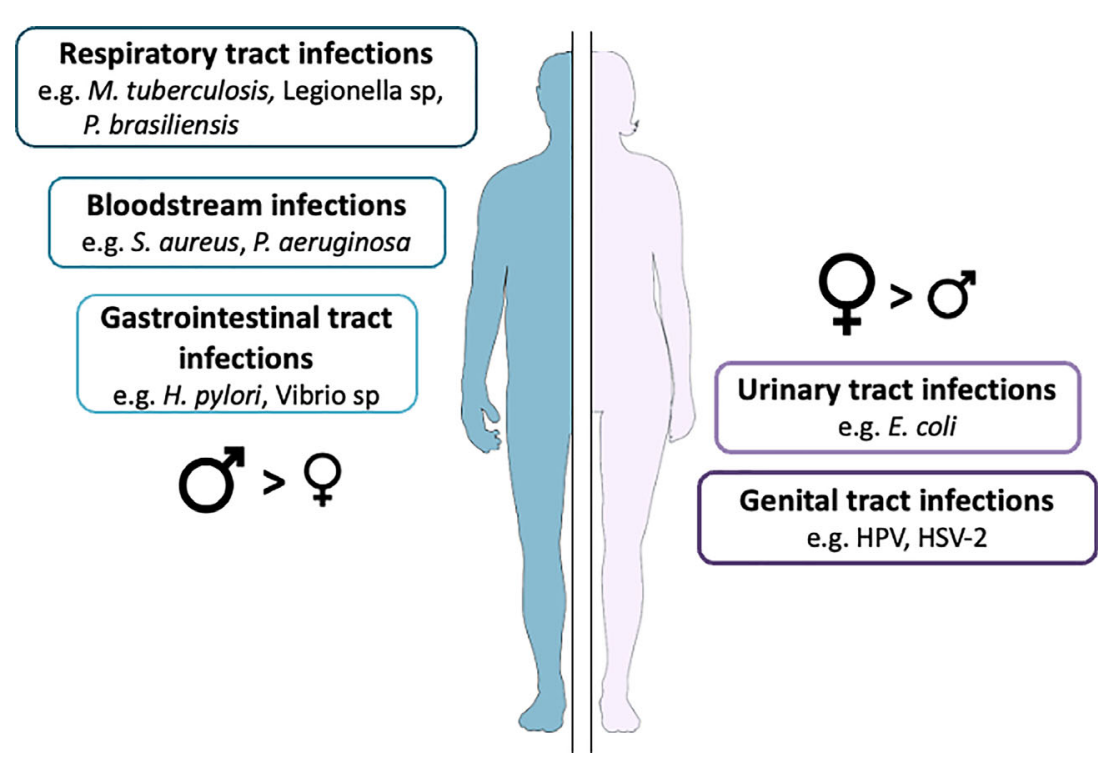

FIGURE 4 | Infection prevalence according to anatomical characteristics. Data extracted from a long-term cohort followed in our institution.

association between sex and both the site of infection and increased risk of infective endocarditis, because age and comorbidities such as diabetes mellitus are likely involved $(106,107)$.

Men develop lower respiratory tract infections more frequently than women, as shown in a two-year European prospective study evaluating the incidence of communityacquired pneumonia (16 vs. 9 cases per 10,000 person-years) $(108,109)$. In contrast, sinusitis and tonsillitis are more frequent in women than in men; here, the smaller size of paranasal sinus ostia in women may account for such dimorphism (110).

\section{Sexual Dimorphism Related to Microorganisms}

In general, men are more affected by bacterial and parasitic infections than women, with the exception of Escherichia coli, Borrelia burgdorferi and Chlamydia trachomatis. In this section, we focus on infectious diseases for which a pronounced sexual dimorphism has been reported at clinical and epidemiological levels.

\section{Bacterial Infections}

Numerous infections caused by intracellular pathogens, such as M. tuberculosis, C. burnetii, Legionella sp., and Brucella sp., exhibit unbalanced $\mathrm{M} / \mathrm{F}$ ratios (Figure $\mathbf{5 A}$ ). We illustrate this point with three examples. Tuberculosis (defined by a clinical diagnosis of tuberculosis disease) exhibits a global $\mathrm{M} / \mathrm{F}$ ratio of 1.7 (112). Although it is estimated that one-third of the world's population has latent $M$. tuberculosis infections, it is also estimated that asymptomatic carriage affects more men than women (33\% vs. 25\%) (113). Among both HIV-negative and HIV-positive individuals, tuberculosis-related mortality is higher in men than in women, with an $\mathrm{M} / \mathrm{F}$ ratio of 1.8 to 1.9 , which is partly related to differences in gender access to healthcare (112). Interestingly, women more often develop extrapulmonary forms of the disease, with $\mathrm{M} / \mathrm{F}$ ratios ranging from 1:1.7 to 1:2.9 in lowincome countries (114).

From the French National Reference Centre for Q fever, the sexual dimorphism was more pronounced during C. burnetii persistent focal infection (M/F sex ratio: 2.8 ) than during acute $Q$ fever (M/F sex ratio: 2.2). The $\mathrm{M} / \mathrm{F}$ sex ratio reached 7.5 in patients with vascular C. burnetii infection, independent of age, whereas the sex ratio related to mortality was $3.8(4,115)$. These differences were not found in children, in whom boys represented $47 \%$ of the cohort (Figure 6) (4). In addition, being male was associated with a higher risk of exhibiting Gisotype anticardiolipin antibodies, which are associated with acute Q fever complications (OR 1.6 [1.3-2.1], $p<0.001)$ (116).

Tropheryma whipplei is a bacterium that causes a rare, chronic, and systemic disease: Whipple's disease. The classical presentation of the disease is characterized by malabsorption syndrome and arthralgias (117). The M/F ratio is 6.0 (118). In rural communities in Gabon, the prevalence of T. whipplei is $23 \%$ in men and $16 \%$ in women $(p=0.05)$, and being a man is identified as a risk factor for T. whipplei asymptomatic carriage (OR 1.6, $p<0.05)(119)$.

Sexual dimorphism is also found for cancers associated with bacterial infections (Figure 7) (120-125). Compared with women, men have a higher incidence of gastric adenocarcinoma associated with $H$. pylori infection and nonHodgkin lymphomas associated with $C$. burnetii infection than women $(122,123)$. In contrast, women are more susceptible than men to developing ocular adnexal lymphoma associated with Chlamydia psittaci infection and primary cutaneous B-cell lymphomas associated with Borrelia burgdorferi infection $(124,125)$. 

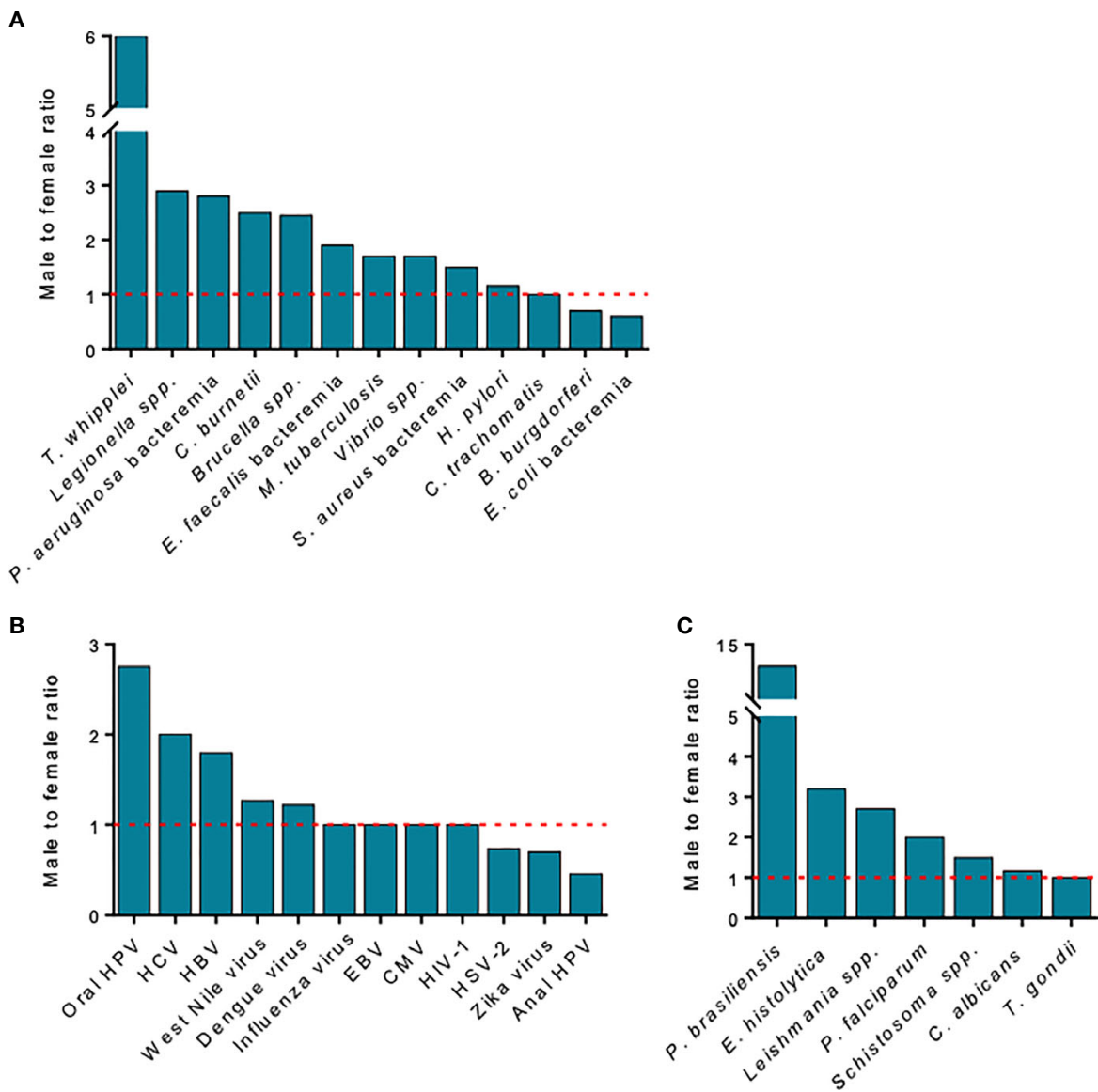

FIGURE 5 | Sex differences in the prevalence of infections. The male-to-female (M/F) ratios for different (A) bacterial, (B) parasitic and fungal, and (C) viral infections are presented. T. whipplei infection occurs in six men for every one woman, but prevalence is similar between men and women for Toxoplasma gondii infection, whereas anal HPV infections are more frequent in women. Data extracted from (111).

Overall, bacterial infections and their consequences, such as infection-associated cancers, are more pronounced in men.

\section{Parasitic and Fungal Infections}

Sexual differences are particularly pronounced in parasitic infections (Figure 5B) (126-128). Although asymptomatic carriage of Entamoeba histolytica is similar in both sexes, invasive amoebiasis affects a higher proportion of men than women (126). Men are also more affected by P. falciparum and Plasmodium vivax infections than women, whereas the mortality associated with $P$. falciparum is higher in women than in men ( $18 \%$ vs. $7.6 \%)$. This observation could be partly explained by anemia along with immunological differences, which is more frequent in pregnant women than in nonpregnant women, the latter being associated with increased mortality in $P$. falciparum infection (127).

There are sex differences in the incidence or manifestations of fungal infections. In paracoccidioidomycosis, this is caused by the fungus Paracoccidioides brasiliensis, where the $\mathrm{M} / \mathrm{F}$ ratio is extremely high (Figure 5B) (128). As reported for bacteriumassociated cancer, parasite-associated cancer exhibits sexual dimorphism. Men account for more than two-thirds of the cases of cholangiocarcinoma associated with Opisthorchis viverrini and Clonorchis sinensis and are more affected by urinary bladder cancer caused by Schistosomia haematobium $(129,130)$.

\section{Viral Infections}

Sexual dimorphism is classically less pronounced in viral infections, albeit differences between men and women have been reported (Figure 5C) (74, 131, 132). HBV and HCV infections are more frequent in men. Women spontaneously clear HCV more efficiently than men (45\% vs. 34\%) $(131,133)$. Finally, some disparities have been observed in infections caused by HIV-1. The HIV-1 viral load in untreated women is up to $40 \%$ lower than in men, but progression to acquired immunodeficiency syndrome (AIDS) is faster in women at similar viremia levels, partly because of increased immune activation in women.

Sex differences have been reported in the incidence and severity of dengue virus infection. The incidence of this infection is higher in men than in women (from 1.5:1 to 2.5:1) (134). In a report from Fiji, men were more likely to develop a lethal presentation than women (63\% of deaths occurring in men) (135). These data could 

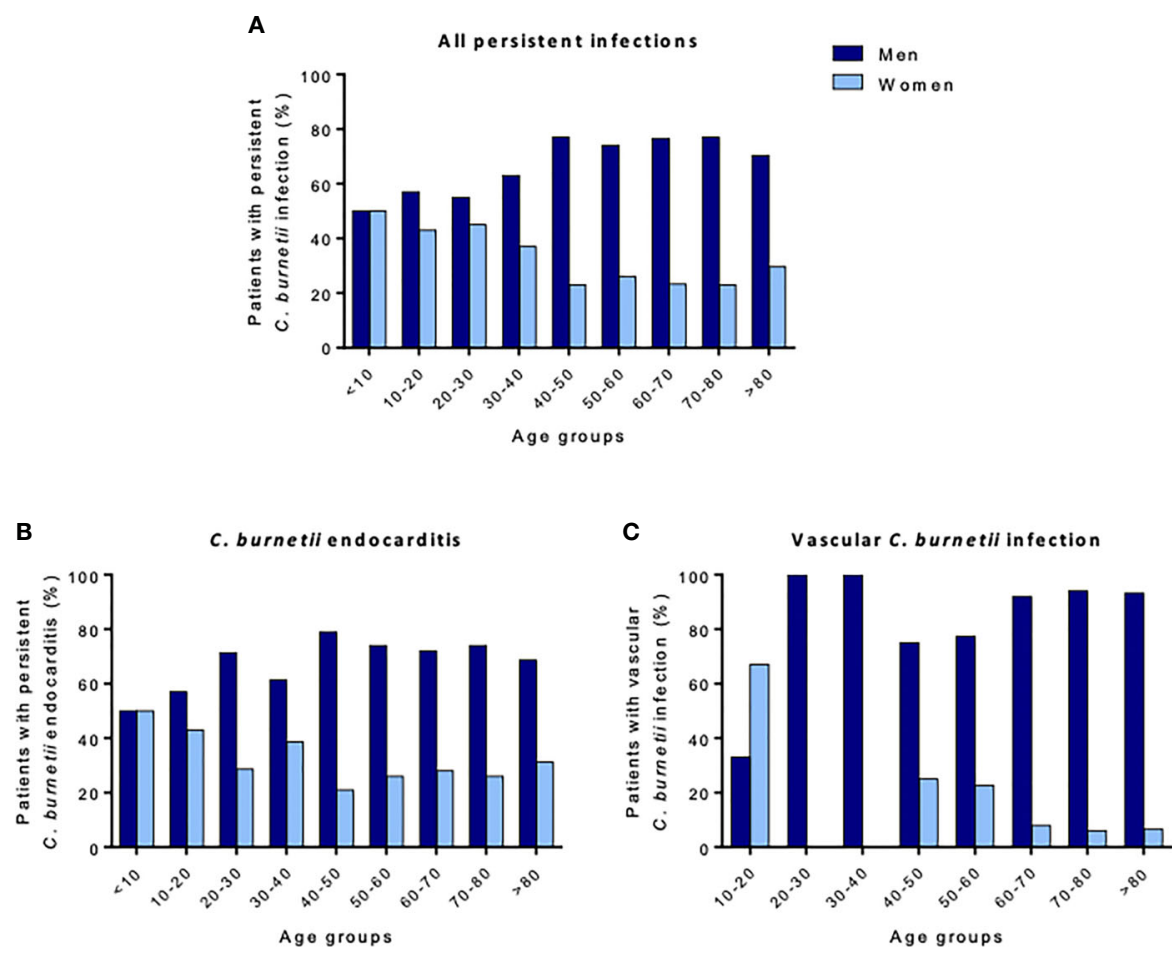

FIGURE 6 | Percentage of patients with persistent $C$. burnetii infection regarding sex and age. The proportion of men and women patients for (A) all persistent C. burnetii infections, (B) C. burnetii endocarditis, and (C) vascular C. burnetii infections are presented. In children, persistent C. burnetii infection affects girls and boys similarly, whereas adult men are mostly affected. After 40 years of age, men represent more than $70 \%$ of patients.

partly be explained by a higher occupational exposure in men, but also by a sex dimorphism in the antibody enhancement process. In fact, pre-existing sub-neutralizing levels of antibodies, through Fc $\gamma$ receptor interaction, can lead to increased intracellular viral uptake and enhanced infection (136). This is illustrated by enhanced dengue severity mediated by maternally acquired heterotypic dengue antibodies (137). However, more animal and clinical studies are needed to explore sex differences in this phenomenon.

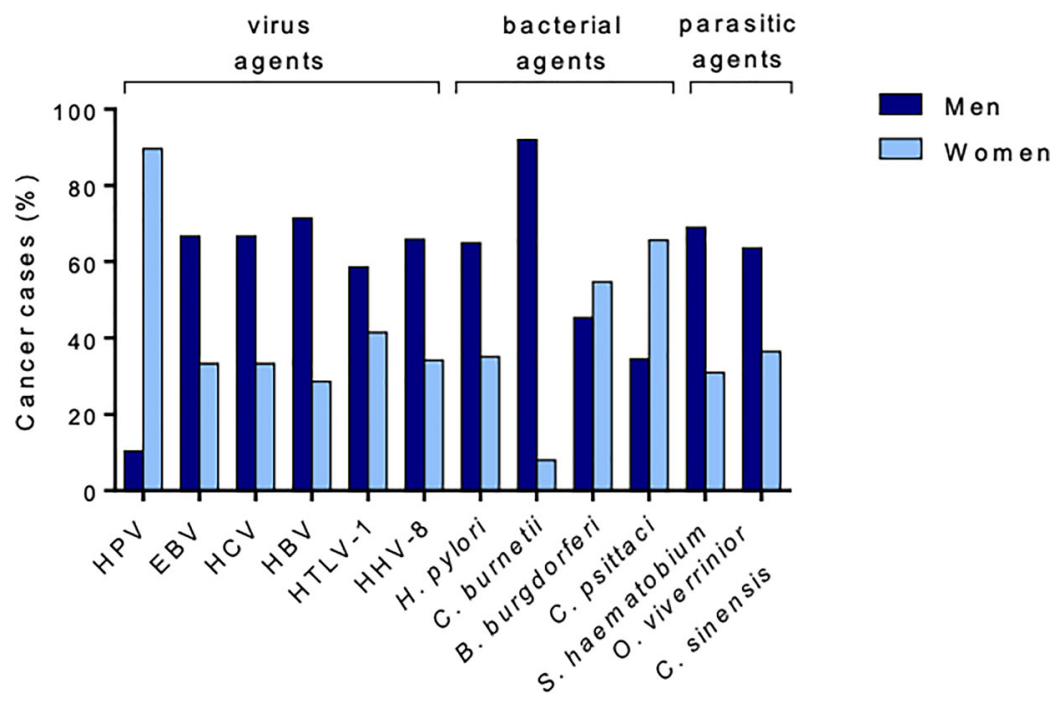

FIGURE 7 | Percentage of cancer cases attributable to infectious agents by sex. Sex disparities are observed in infection-associated cancers. Globally, men are more likely to develop cancer because of infection, except in a few cases, such as HPV infection. 
A sexual dimorphism has been identified in COVID-19 infections. Men were significantly more represented in the group of critical and deceased COVID-19 patients. Conversely, being a woman was associated with a reduced risk of death and a reduced risk of disease progression $(138,139)$. In fact, SARSCoV-2 binds to ACE-2, a protein encoded by the genes of the Xchromosome (95), which is one of the hypotheses for explaining the sexual dimorphism observed in this disease. Recently, we identified an almost exclusively male population suffering from severe COVID-19 and characterized by the neutralization of type I IFN via inborn defects or the presence of antitype 1 IFN autoantibodies (140). It has also been shown that post-acute COVID19 syndrome is more likely to occur in women than in men.

Finally, there is sexual dimorphism in virus-associated cancers, as reported for cancers associated with bacteria or parasites (141-143). After viral hepatitis, men have a two- to four-fold increased risk of developing hepatocellular carcinoma (141). Similarly, after human T cell leukemia virus type 1 infection, men can be up to 3.5 times more susceptible to developing adult $\mathrm{T}$ cell leukemia than women $(142,143)$.

\section{SEXUAL DIMORPHISM FROM A GENDER PERSPECTIVE}

Although hormonal and chromosomic hypotheses are tempting to consider, they cannot explain all the features of sexual dimorphism in infectious diseases. Because of the intricacy of social and biological mechanisms in sex-associated susceptibility to infections, it is necessary to evaluate the influence of sociocultural factors, both at the contextual and individual levels. The latter are critical for analyzing the biological studies in which they may be confounded.

The historical and social organization that is partly based on gender roles may put men and women at risk of contracting specific infections in different ways. Mine workers are five to six times more likely to contract tuberculosis than the general population (144). People working in sewage treatment are exposed to T. whipplei; dockworkers, fishermen, or oyster shuckers to Vibrio sp. infection; slaughterhouse workers to Q fever; and farmers to brucellosis (145, 146). Slaughterhouse workers and farmers are predominantly male in developing countries (67\%), while in industrialized countries, men and women are equally represented in these occupations (147). In the case of schistosomiasis, boys are infected more often than girls (ratio at 1.8), a difference persisting in adults (ratio at 1.5). This is partly explained by the more frequent bathing of boys in stagnant waters (148-150). There is no occupational exposure to C. burnetii $(4,151)$ at variance with brucellosis and bilharziosis $(150,152,153)$.

In sex workers, sexually transmitted infections are more frequent in women than in men, and women sex workers are 13.5 times more likely to contract HIV than other women aged 15-49 years old, even in countries with a high HIV prevalence (154, 155). In developed countries, Treponema pallidum infection affects men in $88 \%$ to $96 \%$ of cases, most of them being men who have sex with men (58\% to $82 \%)$ (156).
Moreover, at the individual level, health behaviors such as healthy lifestyle habits or healthcare-seeking behaviors could explain the gap in vulnerability that can be observed between women and men in terms of specific infectious diseases.

Comorbidities and lifestyle habits influence susceptibility to infections. Consumption of alcohol and tobacco increases the risk of infections, and their complications are higher in men than in women (157). Alcohol consumption is a risk factor for tuberculosis and accelerates liver fibrosis in HCV-infected individuals (158). Smoking is a risk factor for infectious lung diseases, accounting for up to $30 \%$ of the variance in the sex ratio of pulmonary tuberculosis notifications (159). In South India, the risk of progression toward pulmonary tuberculosis shows an $\mathrm{M} / \mathrm{F}$ ratio of 2.7 , whereas the exclusion of smokers and alcohol users reduces the M/F ratio to 1.2 (160). Also, high blood pressure and diabetes mellitus are more common in men than women $(161,162)$.

Finally, gender disparities in the use of healthcare services may influence the course of infectious diseases. For tuberculosis, prevalence surveys show that men are underdiagnosed as compared with women, suggesting that men may be less likely to seek or access healthcare than women $(112,163)$. Consequently, male tuberculosis cases may be underestimated in some countries $(112,163)$. Similarly, antiretroviral therapy coverage among people living with HIV is higher among women (52\%) than men (41\%) (132). This gender gap is likely related to gender norms. Among adult men, the delayed initiation of treatment and reduced adherence to treatment contribute to an increased number of deaths (132).

\section{CONCLUSION}

Infections are multifactorial diseases whose exposition and evolution are influenced by social organization and health behaviors. Biological determinants also influence the course of infectious diseases, which are partially dictated by immune response and subjected to hormonal influences and chromosomal predispositions. Thus, susceptibility to infections changes over the course of an individual's life. After puberty, women are initially less susceptible to infectious diseases because of their ability to mobilize and activate innate and adaptive immune responses, whereas during pregnancy, an immunoregulatory Th2 immune response is promoted. In men, testosterone has immunosuppressive properties. In addition, genetic factors determine the outcome of infections and are involved in susceptibility and resistance to microbial agents. Some microorganisms have developed strategies that take advantage of hormonal or chromosomal influences to survive and multiply. Therefore, sexual dimorphism needs to be integrated into the development of anti-infectious treatments.

\section{AUTHOR CONTRIBUTIONS}

Data curation: LG, CM, IL. Supervision: J-LM, ML. Writing original draft: LG, CM, IL, M-KB. Writing - review and editing: SM, CD, DR, J-LM, ML. All authors contributed to the article and approved the submitted version. 


\section{REFERENCES}

1. Mège J-L, Bretelle F, Leone M. Sex and Bacterial Infectious Diseases. New Microbes New Infections (2018) 26:S100-3. doi: 10.1016/j.nmni.2018.05.010

2. vom Steeg LG, Klein SL. SeXX Matters in Infectious Disease Pathogenesis. PloS Pathog (2016) 12:e1005374. doi: 10.1371/journal.ppat.1005374

3. Sappenfield E, Jamieson DJ, Kourtis AP. Pregnancy and Susceptibility to Infectious Diseases. Infect Dis Obstet Gynecol (2013) 2013:8. doi: 10.1155/ 2013/752852

4. Melenotte C, Protopopescu C, Million M, Edouard S, Carrieri MP, Eldin C, et al. Clinical Features and Complications of Coxiella Burnetii Infections From the French National Reference Center for Q Fever. JAMA Netw Open (2018) 1:e181580. doi: 10.1001/jamanetworkopen.2018.1580

5. Klein SL, Flanagan KL. Sex Differences in Immune Responses. Nat Rev Immunol (2016) 16:626-38. doi: 10.1038/nri.2016.90

6. Carrel L, Willard HF. X-Inactivation Profile Reveals Extensive Variability in X-Linked Gene Expression in Females. Nature (2005) 434:400-4. doi: 10.1038/nature03479

7. Mousavi MJ, Mahmoudi M, Ghotloo S. Escape From X Chromosome Inactivation and Female Bias of Autoimmune Diseases. Mol Med (2020) 26:127. doi: 10.1186/s10020-020-00256-1

8. Karnam G, Rygiel TP, Raaben M, Grinwis GCM, Coenjaerts FE, Ressing ME, et al. CD200 Receptor Controls Sex-Specific TLR7 Responses to Viral Infection. PloS Pathog (2012) 8:e1002710. doi: 10.1371/journal. ppat. 1002710

9. Traub S, Demaria O, Chasson L, Serra F, Desnues B, Alexopoulou L. Sex Bias in Susceptibility to MCMV Infection: Implication of TLR9. PloS One (2012) 7:e45171. doi: 10.1371/journal.pone.0045171

10. Asai K, Hiki N, Mimura Y, Ogawa T, Unou K, Kaminishi M. Gender Differences in Cytokine Secretion by Human Peripheral Blood Mononuclear Cells: Role of Estrogen in Modulating LPS-Induced Cytokine Secretion in an Ex Vivo Septic Model. Shock (2001) 16:340-3. doi: 10.1097/00024382200116050-00003

11. Schröder J, Kahlke V, Staubach K-H, Zabel P, Stüber F. Gender Differences in Human Sepsis. Arch Surg (1998) 133:1200-05. doi: 10.1001/ archsurg.133.11.1200

12. Aomatsu M, Kato T, Kasahara E, Kitagawa S. Gender Difference in Tumor Necrosis Factor- $\alpha$ Production in Human Neutrophils Stimulated by Lipopolysaccharide and Interferon- $\gamma$. Biochem Biophys Res Commun (2013) 441:220-25. doi: 10.1016/j.bbrc.2013.10.042

13. Torcia MG, Nencioni L, Clemente AM, Civitelli L, Celestino I, Limongi D, et al. Sex Differences in the Response to Viral Infections: TLR8 and TLR9 Ligand Stimulation Induce Higher IL10 Production in Males. PloS One (2012) 7. doi: 10.1371/journal.pone.0039853

14. Girard-Joyal O, Faragher A, Bradley K, Kane L, Hrycyk L, Ismail N. Age and Sex Differences in C-Fos Expression and Serum Corticosterone Concentration Following LPS Treatment. Neuroscience (2015) 305:293301. doi: 10.1016/j.neuroscience.2015.06.035

15. Hantsoo L, Kornfield S, Iannelli C, Podcasy J, Metzger D, Sammel MD, et al. Glucocorticoid-immune Response to Acute Stress in Women and Men Living With HIV. J Behav Med (2019) 42:1153-58. doi: 10.1007/s10865-01900029-0

16. Abdullah M, Chai P-S, Chong M-Y, Tohit ERM, Ramasamy R, Pei CP, et al. Gender Effect on In Vitro Lymphocyte Subset Levels of Healthy Individuals. Cell Immunol (2012) 272:214-19. doi: 10.1016/j.cellimm.2011.10.009

17. Fan H, Dong G, Zhao G, Liu F, Yao G, Zhu Y, et al. Gender Differences of B Cell Signature in Healthy Subjects Underlie Disparities in Incidence and Course of SLE Related to Estrogen. J Immunol Res (2014) 2014. doi: 10.1155/ 2014/814598

18. Khurana S, Wu J, Dimitrova M, King LR, Manischewitz J, Graham BS, et al. DNA Priming Prior to Inactivated Influenza a(H5n1) Vaccination Expands the Antibody Epitope Repertoire and Increases Affinity Maturation in a Boost-Interval-Dependent Manner in Adults. J Infect Dis (2013) 208:41317. doi: 10.1093/infdis/jit178

19. Schneider-Hohendorf T, Görlich D, Savola P, Kelkka T, Mustjoki S, Gross CC, et al. Sex Bias in MHC I-Associated Shaping of the Adaptive Immune System. Proc Natl Acad Sci USA (2018) 115:2168-73. doi: 10.1073/ pnas. 1716146115
20. Kovats S, Carreras E, Agrawal H. Sex Steroid Receptors in Immune Cells. In: SL Klein and C Roberts, editors. Sex Hormones and Immunity to Infection. Heidelberg: Springer Berlin Heidelberg (2010). p. 53-91. doi: 10.1007/978-3642-02155-8_3

21. vom Steeg LG, Klein SL. Sex Steroids Mediate Bidirectional Interactions Between Hosts and Microbes. Horm Behav (2017) 88:45-51. doi: 10.1016/ j.yhbeh.2016.10.016

22. Miller L, Hunt JS. Sex Steroid Hormones and Macrophage Function. Life Sci (1996) 59:1-14. doi: 10.1016/0024-3205(96)00122-1

23. Grimaldi CM, Cleary J, Dagtas AS, Moussai D, Diamond B. Estrogen Alters Thresholds for B Cell Apoptosis and Activation. J Clin Invest (2002) 109:1625-33. doi: 10.1172/JCI14873

24. D’Agostino P, Milano S, Barbera C, Di Bella G, La Rosa M, Ferlazzo V, et al. Sex Hormones Modulate Inflammatory Mediators Produced by Macrophages. Ann N Y Acad Sci (1999) 876:426-29. doi: 10.1111/j.17496632.1999.tb07667.x

25. Hamilton JB, Mestler GE. Mortality and Survival: Comparison of Eunuchs With Intact Men and Women in a Mentally Retarded Population. J Gerontol (1969) 24:395-411. doi: 10.1093/geronj/24.4.395

26. Svanberg L. Effects of Estrogen Deficiency in Women Castrated When Young. Acta Obstet Gynecol Scand (1982) 61:11-5. doi: 10.3109/ 00016348209155324

27. Chan ED, Iseman MD. Slender, Older Women Appear to be More Susceptible to Nontuberculous Mycobacterial Lung Disease. Gend Med (2010) 7:5-18. doi: 10.1016/j.genm.2010.01.005

28. Clark RA, Bessinger R. Clinical Manifestations and Predictors of Survival in Older Women Infected With HIV. J Acquir Immune Defic Syndr (1997) 15:341. doi: 10.1097/00042560-199708150-00003

29. Leone M, Honstettre A, Lepidi H, Capo C, Bayard F, Raoult D, et al. Effect of Sex on Coxiella Burnetii Infection: Protective Role of 17betaEstradiol. J Infect Dis (2004) 189:339-45. doi: 10.1086/380798

30. Kaushic C, Zhou F, Murdin AD, Wira CR. Effects of Estradiol and Progesterone on Susceptibility and Early Immune Responses to Chlamydia Trachomatis Infection in the Female Reproductive Tract. Infect Immun (2000) 68:4207-16. doi: 10.1128/IAI.68.7.4207-4216.2000

31. Saia RS, Garcia FM, Cárnio EC. Estradiol Protects Female Rats Against Sepsis Induced by Enterococcus Faecalis Improving Leukocyte Bactericidal Activity. Steroids (2015) 102:17-26. doi: 10.1016/j.steroids.2015.06.016

32. Ohtani M, Ge Z, García A, Rogers AB, Muthupalani S, Taylor NS, et al. 17 $\beta$ Estradiol Suppresses Helicobacter Pylori-Induced Gastric Pathology in Male Hypergastrinemic INS-GAS Mice. Carcinogenesis (2011) 32:1244-50. doi: $10.1093 /$ carcin/bgr072

33. Pung OJ, Tucker AN, Vore SJ, Luster MI. Influence of Estrogen on Host Resistance: Increased Susceptibility of Mice to Listeria Monocytogenes Correlates With Depressed Production of Interleukin 2. Infect Immun (1985) 50:91-6. doi: 10.1128/iai.50.1.91-96.1985

34. Tsuyuguchi K, Suzuki K, Matsumoto H, Tanaka E, Amitani R, Kuze F. Effect of Oestrogen on Mycobacterium Avium Complex Pulmonary Infection in Mice. Clin Exp Immunol (2001) 123:428-34. doi: 10.1046/j.13652249.2001.01474.x

35. Yamamoto Y, Saito H, Setogawa T, Tomioka H. Sex Differences in Host Resistance to Mycobacterium Marinum Infection in Mice. Infect Immun (1991) 59:4089-96. doi: 10.1128/iai.59.11.4089-4096.1991

36. Bini EI, Espinosa DM, Castillo BM, Payán JB, Colucci D, Cruz AF, et al. The Influence of Sex Steroid Hormones in the Immunopathology of Experimental Pulmonary Tuberculosis. PloS One (2014) 9:e93831. doi: 10.1371/journal.pone.0093831

37. Merkel SM, Alexander S, Zufall E, Oliver JD, Huet-Hudson YM. Essential Role for Estrogen in Protection Against Vibrio Vulnificus-Induced Endotoxic Shock. Infect Immun (2001) 69:6119-22. doi: 10.1128/ IAI.69.10.6119-6122.2001

38. Bhavanam S, Snider DP, Kaushic C. Intranasal and Subcutaneous Immunization Under the Effect of Estradiol Leads to Better Protection Against Genital HSV-2 Challenge Compared to Progesterone. Vaccine (2008) 26:6165-72. doi: 10.1016/j.vaccine.2008.08.045

39. Smith SM, Baskin GB, Marx PA. Estrogen Protects Against Vaginal Transmission of Simian Immunodeficiency Virus. J Infect Dis (2000) 182:708-15. doi: $10.1086 / 315776$ 
40. Lotter H, Helk E, Bernin H, Jacobs T, Prehn C, Adamski J, et al. Testosterone Increases Susceptibility to Amebic Liver Abscess in Mice and Mediates Inhibition of Ifn $\gamma$ Secretion in Natural Killer T Cells. PloS One (2013) 8: e55694. doi: 10.1371/journal.pone.0055694

41. Cervantes-Rebolledo C, Moreno-Mendoza N, Morales-Montor J, Torre PDL, Laclette JP, Carrero JC. Gonadectomy Inhibits Development of Experimental Amoebic Liver Abscess in Hamsters Through Downregulation of the Inflammatory Immune Response. Parasite Immunol (2009) 31:447-56. doi: 10.1111/j.1365-3024.2009.01120.x

42. Travi BL, Osorio Y, Melby PC, Chandrasekar B, Arteaga L, Saravia NG. Gender is a Major Determinant of the Clinical Evolution and Immune Response in Hamsters Infected With Leishmania Spp. Infect Immun (2002) 70:2288-96. doi: 10.1128/IAI.70.5.2288-2296.2002

43. Cernetich A, Garver LS, Jedlicka AE, Klein PW, Kumar N, Scott AL, et al. Involvement of Gonadal Steroids and Gamma Interferon in Sex Differences in Response to Blood-Stage Malaria Infection. Infect Immun (2006) 74:3190203. doi: 10.1128/IAI.00008-06

44. Nakazawa M, Fantappie MR, Freeman GL, Eloi-Santos S, Olsen NJ, Kovacs WJ, et al. Schistosoma Mansoni: Susceptibility Differences Between Male and Female Mice can be Mediated by Testosterone During Early Infection. Exp Parasitol (1997) 85:233-40. doi: 10.1006/expr.1997.4148

45. Morales-Montor J, Baig S, Hallal-Calleros C, Damian RT. Taenia Crassiceps: Androgen Reconstitution of the Host Leads to Protection During Cysticercosis. Exp Parasitol (2002) 100:209-16. doi: 10.1016/S0014-4894 (02)00028-0

46. Liesenfeld O, Nguyen TA, Pharke C, Suzuki Y. Importance of Gender and Sex Hormones in Regulation of Susceptibility of the Small Intestine to Peroral Infection With Toxoplasma Gondii Tissue Cysts. J Parasitol (2001) 87:1491-93. doi: 10.1645/0022-3395(2001)087[1491:IOGASH] 2.0.CO;2

47. Rifkind D, Frey JA. Influence of Gonadectomy on Candida Albicans Urinary Tract Infection in CFW Mice. Infect Immun (1972) 5:332-36. doi: 10.1128/ iai.5.3.332-336.1972

48. Pinzan CF, Ruas LP, Casabona-Fortunato AS, Carvalho FC, Roque-Barreira M-C. Immunological Basis for the Gender Differences in Murine Paracoccidioides Brasiliensis Infection. PloS One (2010) 5:e10757. doi: 10.1371/journal.pone.0010757

49. Benten WPM, Ulrich P, Kühn-Velten WN, Vohr H-W, Wunderlich F. Testosterone-Induced Susceptibility to Plasmodium Chabaudi Malaria: Persistence After Withdrawal of Testosterone. J Endocrinol (1997) 153:275-81. doi: 10.1677/joe.0.1530275

50. Textoris J, Ban LH, Capo C, Raoult D, Leone M, Mège J-L. Sex-Related Differences in Gene Expression Following Coxiella Burnetii Infection in Mice: Potential Role of Circadian Rhythm. PloS One (2010) 5:e12190. doi: 10.1371/journal.pone.0012190

51. Chappell PE. Clocks and the Black Box: Circadian Influences on Gonadotropin-Releasing Hormone Secretion. J Neuroendocrinol (2005) 17:119-30. doi: 10.1111/j.1365-2826.2005.01270.x

52. Ghigo E, Honstettre A, Capo C, Gorvel J-P, Raoult D, Mège J-L. Link Between Impaired Maturation of Phagosomes and Defective Coxiella Burnetii Killing in Patients With Chronic Q Fever. J Infect Dis (2004) 190:1767-72. doi: 10.1086/425041

53. Meghari S, Bechah Y, Capo C, Lepidi H, Raoult D, Murray PJ, et al. Persistent Coxiella Burnetii Infection in Mice Overexpressing IL-10: An Efficient Model for Chronic Q Fever Pathogenesis. PloS Pathog (2008) 4:e23. doi: 10.1371/journal.ppat.0040023

54. Botelho MC, Soares R, Vale N, Ribeiro R, Camilo V, Almeida R, et al. Schistosoma Haematobium: Identification of New Estrogenic Molecules With Estradiol Antagonistic Activity and Ability to Inactivate Estrogen Receptor in Mammalian Cells. Exp Parasitol (2010) 126:526-35. doi: 10.1016/j.exppara.2010.06.012

55. Escobedo G, De León-Nava MA, Morales-Montor J. Sex Differences in Parasitic Infections: Beyond the Dogma of Female-Biased Resistance. In: SL Klein and C Roberts, editors. Sex Hormones and Immunity to Infection. Berlin, Heidelberg: Springer Berlin Heidelberg (2010). p. 187-204. doi: 10.1007/978-3-642-02155-8_7

56. Wang S-H, Yeh S-H, Lin W-H, Wang H-Y, Chen D-S, Chen P-J. Identification of Androgen Response Elements in the Enhancer I of
Hepatitis B Virus: A Mechanism for Sex Disparity in Chronic Hepatitis B. Hepatology (2009) 50:1392-402. doi: 10.1002/hep.23163

57. Chan WK, Klock G, Bernard HU. Progesterone and Glucocorticoid Response Elements Occur in the Long Control Regions of Several Human Papillomaviruses Involved in Anogenital Neoplasia. J Virol (1989) 63:326169. doi: 10.1128/jvi.63.8.3261-3269.1989

58. Madani ND, Malloy PJ, Rodriguez-Pombo P, Krishnan AV, Feldman D. Candida Albicans Estrogen-Binding Protein Gene Encodes an Oxidoreductase That is Inhibited by Estradiol. PNAS (1994) 91:922-26. doi: 10.1073/pnas.91.3.922

59. Vilchez G, Espinoza M, D'Onadio G, Saona P, Gotuzzo E. Brucellosis in Pregnancy: Clinical Aspects and Obstetric Outcomes. Int J Infect Dis (2015) 38:95-100. doi: 10.1016/j.ijid.2015.06.027

60. Carcopino X, Raoult D, Bretelle F, Boubli L, Stein A. Q Fever During Pregnancy: A Cause of Poor Fetal and Maternal Outcome. Ann N Y Acad Sci (2009) 1166:79-89. doi: 10.1111/j.1749-6632.2009.04519.x

61. Coste Mazeau P, Hantz S, Eyraud J-L, Donadel L, Lacorre A, Rogez S, et al. Q Fever and Pregnancy: Experience From the Limoges Regional University Hospital. Arch Gynecol Obstet (2016) 294:233-38. doi: 10.1007/s00404-0153958-9

62. Lamont RF, Sobel J, Mazaki-Tovi S, Kusanovic JP, Vaisbuch E, Kim SK, et al. Listeriosis in Human Pregnancy: A Systematic Review. J Perinat Med (2011) 39:227-36. doi: 10.1515/JPM.2011.035

63. He W, Jin Y, Zhu H, Zheng Y, Qian J. Effect of Chlamydia Trachomatis on Adverse Pregnancy Outcomes: A Meta-Analysis. Arch Gynecol Obstet (2020) 302:553-67. doi: 10.1007/s00404-020-05664-6

64. Ahmadzia HK, Heine RP. Diagnosis and Management of Group B Streptococcus in Pregnancy. Obstet Gynecol Clin (2014) 41:629-47. doi: 10.1016/j.ogc.2014.08.009

65. Marrs C, Olson G, Saade G, Hankins G, Wen T, Patel J, et al. Zika Virus and Pregnancy: A Review of the Literature and Clinical Considerations. Am J Perinatol (2016) 33:625-39. doi: 10.1055/s-0036-1580089

66. Alvarado MG, Schwartz DA. Zika Virus Infection in Pregnancy, Microcephaly, and Maternal and Fetal Health: What We Think, What We Know, and What We Think We Know. Arch Pathol Lab Med (2016) 141:2632. doi: 10.5858/arpa.2016-0382-RA

67. Lamont RF, Sobel J, Vaisbuch E, Kusanovic JP, Mazaki-Tovi S, Kim SK, et al. Parvovirus B19 Infection in Human Pregnancy. BJOG (2011) 118:175-86. doi: 10.1111/j.1471-0528.2010.02749.x

68. Borgia G, Carleo MA, Gaeta GB, Gentile I. Hepatitis B in Pregnancy. World J Gastroenterol (2012) 18:4677-83. doi: 10.3748/wjg.v18.i34.4677

69. Silasi M, Cardenas I, Racicot K, Kwon J-Y, Aldo P, Mor G. Viral Infections During Pregnancy. Am J Reprod Immunol (2015) 73:199-213. doi: 10.1111/ aji.12355

70. Siston AM, Rasmussen SA, Honein MA, Fry AM, Seib K, Callaghan WM, et al. Pandemic 2009 Influenza A(H1N1) Virus Illness Among Pregnant Women in the United States. JAMA (2010) 303:1517-25. doi: 10.1001/ jama.2010.479

71. Robinson DP, Klein SL. Pregnancy and Pregnancy-Associated Hormones Alter Immune Responses and Disease Pathogenesis. Horm Behav (2012) 62:263-71. doi: 10.1016/j.yhbeh.2012.02.023

72. Jamieson DJ, Theiler RN, Rasmussen SA. Emerging Infections and Pregnancy. Emerg Infect Dis (2006) 12:1638-43. doi: 10.3201/ eid1211.060152

73. Kochar DK, Thanvi I, Joshi A, Shubhakaran, Agarwal N, Jain N. Mortality Trends in Falciparum Malaria-Effect of Gender Difference and Pregnancy. J Assoc Physicians India (1999) 47:774-78.

74. Gabriel G, Arck PC. Sex, Immunity and Influenza. J Infect Dis (2014) 209 Suppl 3:S93-99. doi: 10.1093/infdis/jiu020

75. Machado CR, Machado ES, Rohloff RD, Azevedo M, Campos DP, de Oliveira RB, et al. Is Pregnancy Associated With Severe Dengue? A Review of Data From the Rio De Janeiro Surveillance Information System. PloS Negl Trop Dis (2013) 7:e2217. doi: 10.1371/journal.pntd.0002217

76. Straub RH. The Complex Role of Estrogens in Inflammation. Endocr Rev (2007) 28:521-74. doi: 10.1210/er.2007-0001

77. Bouman A, Heineman MJ, Faas MM. Sex Hormones and the Immune Response in Humans. Hum Reprod Update (2005) 11:411-23. doi: 10.1093/ humupd/dmi008 
78. Pazos M, Sperling RS, Moran TM, Kraus TA. The Influence of Pregnancy on Systemic Immunity. Immunol Res (2012) 54:254-61. doi: 10.1007/s12026012-8303-9

79. Kraus TA, Engel SM, Sperling RS, Kellerman L, Lo Y, Wallenstein S, et al. Characterizing the Pregnancy Immune Phenotype: Results of the Viral Immunity and Pregnancy (VIP) Study. J Clin Immunol (2012) 32:300-11. doi: $10.1007 /$ s10875-011-9627-2

80. Kawai T, Akira S. TLR Signaling. Cell Death Differ (2006) 13:816-25. doi: $10.1038 /$ sj.cdd. 4401850

81. Bustamante J, Picard C, Boisson-Dupuis S, Abel L, Casanova J-L. Genetic Lessons Learned From X-Linked Mendelian Susceptibility to Mycobacterial Diseases: X-Linked Susceptibility to Mycobacterial Diseases. Ann N Y Acad Sci (2011) 1246:92-101. doi: 10.1111/j.1749-6632.2011.06273.x

82. Fish EN. The X-Files in Immunity: Sex-Based Differences Predispose Immune Responses. Nat Rev Immunol (2008) 8:737-44. doi: 10.1038/ nri2394

83. Dai R, Ahmed SA. MicroRNA, a New Paradigm for Understanding Immunoregulation, Inflammation, and Autoimmune Diseases. Transl Res (2011) 157:163-79. doi: 10.1016/j.trsl.2011.01.007

84. Eulalio A, Schulte L, Vogel J. The Mammalian microRNA Response to Bacterial Infections. RNA Biol (2012) 9:742-50. doi: 10.4161/rna.20018

85. Dorhoi A, Iannaccone M, Farinacci M, Faé KC, Schreiber J, Moura-Alves P, et al. MicroRNA-223 Controls Susceptibility to Tuberculosis by Regulating Lung Neutrophil Recruitment. J Clin Invest (2013) 123:4836-48. doi: $10.1172 /$ JCI67604

86. Arnold AP, Chen X. What Does the "Four Core Genotypes" Mouse Model Tell Us About Sex Differences in the Brain and Other Tissues? Front Neuroendocrinol (2009) 30:1-9. doi: 10.1016/j.yfrne.2008.11.001

87. Wang J, Syrett CM, Kramer MC, Basu A, Atchison ML, Anguera MC. Unusual Maintenance of X Chromosome Inactivation Predisposes Female Lymphocytes for Increased Expression From the Inactive X. Proc Natl Acad Sci USA (2016) 113:E2029-38. doi: 10.1073/pnas.1520113113

88. Hagen SH, Henseling F, Hennesen J, Savel H, Delahaye S, Richert L, et al. Heterogeneous Escape From X Chromosome Inactivation Results in Sex Differences in Type I IFN Responses at the Single Human pDC Level. Cell Rep (2020) 33:108485. doi: 10.1016/j.celrep.2020.108485

89. Souyris M, Cenac C, Azar P, Daviaud D, Canivet A, Grunenwald S, et al. TLR7 Escapes X Chromosome Inactivation in Immune Cells. Sci Immunol (2018) 3:eaap8855. doi: 10.1126/sciimmunol.aap8855

90. Siddiqui RA, Sauermann U, Altmüller J, Fritzer E, Nothnagel M, Dalibor N, et al. X Chromosomal Variation is Associated With Slow Progression to AIDS in HIV-1-Infected Women. Am J Hum Genet (2009) 85:228-39. doi: 10.1016/j.ajhg.2009.07.013

91. Dalgic N, Tekin D, Kayaalti Z, Cakir E, Soylemezoglu T, Sancar M. Relationship Between Toll-Like Receptor 8 Gene Polymorphisms and Pediatric Pulmonary Tuberculosis. Dis Markers (2011). doi: 10.3233/ DMA-2011-0800

92. Fortin A, Abel L, Casanova JL, Gros P. Host Genetics of Mycobacterial Diseases in Mice and Men: Forward Genetic Studies of BCG-Osis and Tuberculosis. Annu Rev Genomics Hum Genet (2007) 8:163-92. doi: 10.1146/annurev.genom.8.080706.092315

93. Cussigh A, Falleti E, Fabris C, Bitetto D, Cmet S, Fontanini E, et al. Interleukin 6 Promoter Polymorphisms Influence the Outcome of Chronic Hepatitis C. Immunogenetics (2011) 63:33-41. doi: 10.1007/s00251-0100491-7

94. Schott E, Witt H, Hinrichsen H, Neumann K, Weich V, Bergk A, et al. Gender-Dependent Association of CTLA4 Polymorphisms With Resolution of Hepatitis C Virus Infection. J Hepatol (2007) 46:372-80. doi: 10.1016/ j.jhep.2006.09.011

95. Li Y, Jerkic M, Slutsky AS, Zhang H. Molecular Mechanisms of Sex Bias Differences in COVID-19 Mortality. Crit Care (2020) 24:405. doi: 10.1186/ s13054-020-03118-8

96. Krementsov DN, Case LK, Dienz O, Raza A, Fang Q, Ather JL, et al. Genetic Variation in Chromosome Y Regulates Susceptibility to Influenza A Virus Infection. PNAS (2017) 114:3491-96. doi: 10.1073/pnas.1620889114

97. Case LK, Toussaint L, Moussawi M, Roberts B, Saligrama N, Brossay L, et al. Chromosome Y Regulates Survival Following Murine Coxsackievirus B3
Infection. G3: Genes Genom Genet (2012) 2:115-21. doi: 10.1534/ g3.111.001610

98. Fortin A, Stevenson MM, Gros P. Complex Genetic Control of Susceptibility to Malaria in Mice. Genes Immun (2002) 3:177-86. doi: 10.1038/ sj.gene. 6363841

99. Roberts M, Alexander J, Blackwell JM. Genetic Analysis of Leishmania Mexicana Infection in Mice: Single Gene (Scl-2) Controlled Predisposition to Cutaneous Lesion Development. J Immunogenet (1990) 17:89-100. doi: 10.1111/j.1744-313X.1990.tb00862.x

100. Brownstein DG, Gras L. Chromosome Mapping of Rmp-4, a GonadDependent Gene Encoding Host Resistance to Mousepox. J Virol (1995) 69:6958-64. doi: 10.1128/jvi.69.11.6958-6964.1995

101. Dielubanza EJ, Schaeffer AJ. Urinary Tract Infections in Women. Med Clin (2011) 95:27-41. doi: 10.1016/j.mcna.2010.08.023

102. Stapleton AE. The Vaginal Microbiota and Urinary Tract Infection. Microbiol Spectr (2016) 4(6):10.1128/microbiolspec.UTI-0025-2016 doi: 10.1128/microbiolspec.UTI-0025-2016

103. Harrington RD, Hooton TM. Urinary Tract Infection Risk Factors and Gender. J Gend Specif Med (2000) 3:27-34.

104. Magliano E, Grazioli V, Deflorio L, Leuci AI, Mattina R, Romano P, et al. Gender and Age-Dependent Etiology of Community-Acquired Urinary Tract Infections. ScientificWorldJournal (2012). doi: 10.1100/2012/349597

105. Reiter PL, Pendergraft WF, Brewer NT. Meta-Analysis of Human Papillomavirus Infection Concordance. Cancer Epidemiol Biomarkers Prev (2010) 19:2916-31. doi: 10.1158/1055-9965.EPI-10-0576

106. Sambola A, Fernández-Hidalgo N, Almirante B, Roca I, González-Alujas T, Serra B, et al. Sex Differences in Native-Valve Infective Endocarditis in a Single Tertiary-Care Hospital. Am J Cardiol (2010) 106:92-8. doi: 10.1016/ j.amjcard.2010.02.019

107. Aksoy O, Meyer LT, Cabell CH, Kourany WM, Pappas PA, Sexton DJ. Gender Differences in Infective Endocarditis: Pre- and Co-Morbid Conditions Lead to Different Management and Outcomes in Female Patients. Scand J Infect Dis (2007) 39:101-7. doi: 10.1080/00365540600993285

108. Gutiérrez F, Masiá M, Mirete C, Soldán B, Carlos Rodríguez J, Padilla S, et al. The Influence of Age and Gender on the Population-Based Incidence of Community-Acquired Pneumonia Caused by Different Microbial Pathogens. J Infect (2006) 53:166-74. doi: 10.1016/j.jinf.2005.11.006

109. Mauvais-Jarvis F, Bairey Merz N, Barnes PJ, Brinton RD, Carrero J-J, DeMeo DL, et al. Sex and Gender: Modifiers of Health, Disease, and Medicine. Lancet (2020) 396:565-82. doi: 10.1016/S0140-6736(20)31561-0

110. Falagas ME, Mourtzoukou EG, Vardakas KZ. Sex Differences in the Incidence and Severity of Respiratory Tract Infections. Respir Med (2007) 101:1845-63. doi: 10.1016/j.rmed.2007.04.011

111. Plummer M, de Martel C, Vignat J, Ferlay J, Bray F, Franceschi S. Global Burden of Cancers Attributable to Infections in 2012: A Synthetic Analysis. Lancet Glob Health (2016) 4:e609-16. doi: 10.1016/S2214-109X(16)30143-7

112. WHO Tuberculosis Report. In: WHO | Global Tuberculosis Report 2017. WHO Tuberculosis Report. Available at: http://www.who.int/tb/ publications/global_report/en.

113. Ting W-Y, Huang S-F, Lee M-C, Lin Y-Y, Lee Y-C, Feng J-Y, et al. Gender Disparities in Latent Tuberculosis Infection in High-Risk Individuals: A Cross-Sectional Study. PloS One (2014) 9:e110104. doi: 10.1371/ journal.pone.0110104

114. Katsnelson A. Beyond the Breath: Exploring Sex Differences in Tuberculosis Outside the Lungs. Nat Med (2017) 23:398-401. doi: 10.1038/nm0417-398

115. Houpikian P, Raoult D. Blood Culture-Negative Endocarditis in a Reference Center: Etiologic Diagnosis of 348 Cases. Med (Baltimore) (2005) 84:162-73. doi: 10.1097/01.md.0000165658.82869.17

116. Melenotte C, Gay L, Mezouar S, Bardin N, Raoult D, Mège J-L. The Sexual Dimorphism of Anticardiolipin Autoantibodies in Acute Q Fever Patients. Clin Microbiol Infect (2019) 25:763-e1. doi: 10.1016/j.cmi.2019.02.030

117. Lagier J-C, Raoult D. Whipple's Disease and Tropheryma Whipplei Infections: When to Suspect Them and How to Diagnose and Treat Them. Curr Opin Infect Dis (2018) 31:463-70. doi: 10.1097/ QCO.0000000000000489

118. Fenollar F, Puéchal X, Raoult D. Whipple's Disease. N Engl J Med (2007) 356:55-66. doi: 10.1056/NEJMra062477 
119. Ramharter M, Harrison N, Bühler T, Herold B, Lagler H, Lötsch F, et al. Prevalence and Risk Factor Assessment of Tropheryma Whipplei in a Rural Community in Gabon: A Community-Based Cross-Sectional Study. Clin Microbiol Infect (2014) 20:1189-94. doi: 10.1111/1469-0691.12724

120. Melenotte C, Mezouar S, Mège J-L, Gorvel J-P, Kroemer G, Raoult D. Bacterial Infection and non-Hodgkin's Lymphoma. Crit Rev Microbiol (2020) 46:270-87. doi: 10.1080/1040841X.2020.1760786

121. van Roeden SE, Houwelingen Fv, Donkers CMJ, Hogewoning SJ, de Lange MMA, Hoek Wvd, et al. Exposure to Coxiella Burnetii and Risk of nonHodgkin Lymphoma: A Retrospective Population-Based Analysis in the Netherlands. Lancet Haematol (2018) 5:e211-19. doi: 10.1016/S2352-3026 (18)30038-3

122. Melenotte C, Million M, Audoly G, Gorse A, Dutronc H, Roland G, et al. BCell non-Hodgkin Lymphoma Linked to. Coxiella Burnetii Blood (2016) 127:113-21. doi: 10.1182/blood-2015-04-639617

123. Correa P, Houghton J. Carcinogenesis of Helicobacter Pylori. Gastroenterol (2007) 133:659-72. doi: 10.1053/j.gastro.2007.06.026

124. Ferreri AJM, Guidoboni M, Ponzoni M, De Conciliis C, Dell'Oro S, Fleischhauer K, et al. Evidence for an Association Between Chlamydia Psittaci and Ocular Adnexal Lymphomas. J Natl Cancer Inst (2004) 96:586-94. doi: 10.1093/jnci/djh102

125. Colli C, Leinweber B, Müllegger R, Chott A, Kerl H, Cerroni L. Borrelia Burgdorferi-Associated Lymphocytoma Cutis: Clinicopathologic, Immunophenotypic, and Molecular Study of 106 Cases. J Cutan Pathol (2004) 31:232-40. doi: 10.1111/j.0303-6987.2003.00167.x

126. Acuna-Soto R, Maguire JH, Wirth DF. Gender Distribution in Asymptomatic and Invasive Amebiasis. Am J Gastroenterol (2000) 95:1277-83. doi: 10.1111/j.1572-0241.2000.01525.x

127. Pathak S, Rege M, Gogtay NJ, Aigal U, Sharma SK, Valecha N, et al. AgeDependent Sex Bias in Clinical Malarial Disease in Hypoendemic Regions. PloS One (2012) 7:e35592. doi: 10.1371/journal.pone.0035592

128. Bellissimo-Rodrigues F, Bollela VR, Da Fonseca BAL, Martinez R. Endemic Paracoccidioidomycosis: Relationship Between Clinical Presentation and Patients' Demographic Features. Med Mycol (2013) 51:313-18. doi: $10.3109 / 13693786.2012 .714529$

129. Watanapa P, Watanapa WB. Liver Fluke-Associated Cholangiocarcinoma. BJS (2002) 89:962-70. doi: 10.1046/j.1365-2168.2002.02143.x

130. Fried B, Reddy A, Mayer D. Helminths in Human Carcinogenesis. Cancer Lett (2011) 305:239-49. doi: 10.1016/j.canlet.2010.07.008

131. Rantala M, Van De LMJ. Surveillance and Epidemiology of Hepatitis B and C in Europe - A Review. Eurosurveillance (2008) 13:18880. doi: 10.2807/ ese.13.21.18880-en

132. WHO AIDS Update. In: WHO | Global AIDS Update. WHO. Available at: http://www.who.int/hiv/pub/arv/global-aids-update-2016-pub/en/.

133. Bakr I, Rekacewicz C, Hosseiny ME, Ismail S, Daly ME, El-Kafrawy S, et al. Higher Clearance of Hepatitis C Virus Infection in Females Compared With Males. Gut (2006) 55:1183-87. doi: 10.1136/gut.2005.078147

134. Kumar M, Verma R, Mishra B. Prevalence of Dengue Fever in Western Uttar Pradesh, India: A Gender-Based Study. Int J App Basic Med Res (2020) 10:8. doi: 10.4103/ijabmr.IJABMR_337_18

135. School of Public Health and Primary Care, College of Medicine, Nursing and Health Sciences and Fiji National University, Suva, Fiji, Getahun A, Batikawai A, Nand D, et al. Dengue in Fiji: Epidemiology of the 2014 DENV-3 Outbreak. WPSAR (2019) 10:31-8. doi: 10.5365/wpsar.2018. 9.3.001

136. Gan ES, Ting DHR, Chan KR. The Mechanistic Role of Antibodies to Dengue Virus in Protection and Disease Pathogenesis. Expert Rev Anti Infect Ther (2017) 15:111-19. doi: 10.1080/14787210.2017.1254550

137. Ng JKW, Zhang SL, Tan HC, Yan B, Maria Martinez Gomez J, Tan WY, et al. First Experimental In Vivo Model of Enhanced Dengue Disease Severity Through Maternally Acquired Heterotypic Dengue Antibodies. PloS Pathog (2014) 10:e1004031. doi: 10.1371/journal.ppat.1004031

138. Lakbar I, Luque-Paz D, Mège J-L, Einav S, Leone M. COVID-19 Gender Susceptibility and Outcomes: A Systematic Review. PloS One (2020) 15: e0241827. doi: 10.1371/journal.pone.0241827

139. Gebhard C, Regitz-Zagrosek V, Neuhauser HK, Morgan R, Klein SL. Impact of Sex and Gender on COVID-19 Outcomes in Europe. Biol Sex Differ (2020) 11:29. doi: 10.1186/s13293-020-00304-9
140. Bastard P, Rosen LB, Zhang Q, Michailidis E, Hoffmann H-H, Zhang Y, et al. Autoantibodies Against Type I IFNs in Patients With Life-Threatening COVID-19. Science (2020) 370(6515):eabd4585. doi: 10.1126/science.abd4585

141. El-Serag HB. Epidemiology of Viral Hepatitis and Hepatocellular Carcinoma. Gastroenterol (2012) 142:1264-73.el. doi: 10.1053/j.gastro.2011.12.061

142. Arisawa K, Soda M, Endo S, Kurokawa K, Katamine S, Shimokawa I, et al. Evaluation of Adult T-Cell Leukemia/Lymphoma Incidence and Its Impact on non-Hodgkin Lymphoma Incidence in Southwestern Japan. Int J Cancer (2000) 85:319-24. doi: 10.1002/(SICI)1097-0215(20000201)85:3<319::AIDIJC4>3.0.CO;2-B

143. Hisada M, Okayama A, Spiegelman D, Mueller NE, Stuver SO. Sex-Specific Mortality From Adult T-Cell Leukemia Among Carriers of Human TLymphotropic Virus Type I. Int J Cancer (2001) 91:497-99. doi: 10.1002/ 1097-0215(20010215)91:4<497::AID-IJC1044>3.0.CO;2-A

144. Stuckler D, Basu S, McKee M, Lurie M. Mining and Risk of Tuberculosis in Sub-Saharan Africa. Am J Public Health (2011) 101:524-30. doi: 10.2105/ AJPH.2009.175646

145. Puéchal X. Whipple's Disease. Ann Rheum Dis (2013) 72:797-803. doi: 10.1136/annrheumdis-2012-202684

146. Hlady WG, Klontz KC. The Epidemiology of Vibrio Infections in Florida, 1981-1993. J Infect Dis (1996) 173:1176-83. doi: 10.1093/infdis/173.5.1176

147. FAO (Food, Organization). A. The State of Food and Agriculture, 2010-2011. In: Women in Agriculture: Closing the Gender Gap for Development. FAO Rome (2011).

148. Ladan MU, Abubakar U, Abdullahi K, Bunza MDA, Nasiru M, Ladan MJ. Gender and Age-Specific Prevalence of Urinary Schistosomiasis in Selected Villages Near a Dam Site in Gusau Local Government Area, Zamfara State, Nigeria. Nigerian J Parasitol (2011) 32.

149. Kapito-Tembo AP, Mwapasa V, Meshnick SR, Samanyika Y, Banda D, Bowie C, et al. Prevalence Distribution and Risk Factors for Schistosoma Hematobium Infection Among School Children in Blantyre, Malawi. PloS Negl Trop Dis (2009) 3:e361. doi: 10.1371/journal.pntd.0000361

150. Guerra-Silveira F, Abad-Franch F. Sex Bias in Infectious Disease Epidemiology: Patterns and Processes. PloS One (2013) 8:e62390. doi: 10.1371/journal.pone.0062390

151. Dupont H, Raoult D, Brouqui P, Janbon F, Peyramond D, Weiller P-J, et al. Epidemiologic Features and Clinical Presentation of Acute Q Fever in Hospitalized Patients: 323 French Cases. Am J Med (1992) 93:427-34. doi: 10.1016/0002-9343(92)90173-9

152. Rahman AKMA, Dirk B, Fretin D, Saegerman C, Ahmed MU, Muhammad $\mathrm{N}$, et al. Seroprevalence and Risk Factors for Brucellosis in a High-Risk Group of Individuals in Bangladesh. Foodborne Pathog Dis (2012) 9:190-97. doi: $10.1089 /$ fpd.2011.1029

153. Ali S, Ali Q, Neubauer H, Melzer F, Elschner M, Khan I, et al. Seroprevalence and Risk Factors Associated With Brucellosis as a Professional Hazard in Pakistan. Foodborne Pathog Dis (2013) 10:500-5. doi: 10.1089/fpd.2012.1360

154. Les Lettres De L'observatoire National Des Violences Faites Aux Femmes (ONVF). Prostitution En France: Ampleur Du Phénomène Impact Sur Les Personnes Prostituees (2015).

155. WHO. Guidelines: Prevention and Treatment of HIV and Other Sexually Transmitted Infections for Sex Workers in Low- and Middle-Income Countries. Geneva: World Health Organization (2012).

156. Amelot F, Picot E, Meusy A, Rousseau C, Brun M, Guillot B. Syphilis in Montpellier, France, From 2002 to 2011: Survey in a Free Hospital Screening Centre for Venereal Disease and in the Dermatology Unit of a Regional Public Hospital. Ann Dermatol Venereol (2015) 142:742-50. doi: 10.1016/ j.annder.2015.07.008

157. Hawkes S, Buse K. Gender and Global Health: Evidence, Policy, and Inconvenient Truths. Lancet (2013) 381:1783-87. doi: 10.1016/S0140-6736 (13)60253-6

158. Wilsnack RW, Wilsnack SC, Kristjanson AF, Vogeltanz-Holm ND, Gmel G. Gender and Alcohol Consumption: Patterns From the Multinational GENACIS Project. Addiction (2009) 104:1487-500. doi: 10.1111/j.1360-0443.2009.02696.x

159. Watkins RE, Plant AJ. Does Smoking Explain Sex Differences in the Global Tuberculosis Epidemic? Epidemiol Infect (2006) 134:333-39. doi: 10.1017/ S0950268805005042

160. Balasubramanian R, Garg R, Santha T, Gopi PG, Subramani R, Chandrasekaran V, et al. Gender Disparities in Tuberculosis: Report From 
a Rural DOTS Programme in South India. Int J Tuberc Lung Dis (2004) 8:323-32.

161. Benjamin EJ, Muntner P, Alonso A, Bittencourt MS, Callaway CW, Carson AP, et al. Heart Disease and Stroke Statistics-2019 Update: A Report From the American Heart Association. Circulation (2019) 139:e56-28. doi: 10.1161/CIR.0000000000000659

162. Barison A, Aimo A, Castiglione V, Arzilli C, Lupón J, Codina P, et al. Cardiovascular Disease and COVID-19: Les Liaisons Dangereuses. Eur J Prev Cardiol (2020) 27:1017-25. doi: 10.1177/2047487320924501

163. Horton KC, MacPherson P, Houben RMGJ, White RG, Corbett EL. Sex Differences in Tuberculosis Burden and Notifications in Lowand Middle-Income Countries: A Systematic Review and MetaAnalysis. PloS Med (2016) 13:e1002119. doi: 10.1371/journal.pmed. 1002119
Conflict of Interest: ML served as speaker for MSD, Aspen and as consultant for Amomed, Ambuand Gilead.

The remaining authors declare that the research was conducted in the absence of any commercial or financial relationships that could be construed as a potential conflict of interest.

Copyright (c) 2021 Gay, Melenotte, Lakbar, Mezouar, Devaux, Raoult, Bendiane, Leone and Mège. This is an open-access article distributed under the terms of the Creative Commons Attribution License (CC BY). The use, distribution or reproduction in other forums is permitted, provided the original author(s) and the copyright owner(s) are credited and that the original publication in this journal is cited, in accordance with accepted academic practice. No use, distribution or reproduction is permitted which does not comply with these terms. 